\title{
Algumas Páginas sobre a Velha Academia de Direito de São Paulo.
}

\author{
Carlos Penteado de Rezende
}

Bacharel em Direito pela Faculdade de Direito da
Universidade de São Paulo. Sócio Emérito do
Instituto Histórico e Geográfico de São Paulo.
Sócio Correspondente do Instituto Histórico e
Geográfico de Minas Gerais

"(...) eu direi, bem alto e forte, para que todos ouçam, o que valem esses esforços e o que são estudantes de São Paulo"

(Pessanha Póvoa, Anos Acadêmicos, Edição de 1870).

Sumário: I. Pequena Antologia. Textos de Interesse para a História da Faculdade de Direito, comentados. II. Informações Coligidas pelo Marechal Daniel Pedro Müller; transcrição da Tabela n. 20, referente às atividades Acadêmicas de 1836. III. Os Viajantes. Observaçóes e Comentários que fizeram sobre a Antiga Faculdade de Direito. IV. Os que ficaram nobres: Relação dos Bacharéis por Säo Paulo que mereceram Títulos Nobiliárquicos.

\section{Pequena Antologia. Textos de Interesse para a História da Faculdade de Direito, Comentados.}

\section{Bernardo Guimarães}

1 - Existe na literatura brasileira algum romance, escrito por antigo estudante, em que a Faculdade de Direito e a Paulicéia do século XIX, na sua realidade autêntica e hábitos peculiares, ressurjam diante de nós ainda com possibilidades de sugestionar e convencer os leitores das novas gerações?

Existe. o título é Rosaura, a Engeitada; o autor, o mineiro BERNARDo GUIMARÃEs, que cursou direito em São Paulo de 1847 a 1851, colando grau em março de 1852, no mês anterior ao falecimento do colega Àlvares de Azevedo.

Foi Bernardo Guimarães um modelo de estudante. Mas, não pela aplicação, assiduidade às aulas ou patrocínio dos len- 
tes. As qualidades, que possuía, desenvolveu-as nas rodas acadêmicas. Modelo se tornou, entre os companheiros, como rapaz folgazão e imaginativo, improvisador de memoráveis tertúlias, ágapes e serenatas; e graças aos seus dotes de poeta e violonista.

Francisco de Paula Ferreira de Rezende, também mineiro, conviveu com ele em São Paulo, por aquele tempo, e testemunhou no livro Minhas Recordações que o seu conterrâneo era boêmio, beberrão e autor de versos satíricos, que circulavam apenas entre os acadêmicos; como contraste, benquisto por todos, talentosc, "revelando às vezes verdadeiros assomos de orgulho, de patriotismo, e de muitos outros sentimentos nobres".

Os romances de BERNARDo GUIMARÃEs, escritos num estilo livre de pedantismos culturais, sem afetações, bem à brasileira, porém com laivos românticos, formam um conjunto desigual. Descobre-se neles a intenção do autor em fixar no papel paisagens e cenas, tipos e personagens, histórias e lendas, tudo a revelar um Brasil latente e legítimo, ainda com índios, negros e caboclos avultando na massa da população e influenciando costumes e tradições. Um Brasil que o autor adivinhava em transformação lenta e implacável e cujas raízes antigas era preciso segurar firmemente no solo da Pátria, para que não viesse a perder a sua identidade. Um Brasil mestiço, cristão e generoso, apto a receber novos caldeamentos.

o amplo painel, que idealizou, carece de pinceladas mais artísticas, em suma, de acabamento. Mas as suas figuras despertam simpatia, demonstram o calor humano de quem as criou. Ficou-lhe o mérito de, entre as abusões do romantismo importado da Europa (e que tanto contagiaram os seus colegas da Academia), ter-se conservado fiel às vozes da terra, produzindo uma obra de sentido brasileiro, tal qual o cearense JosÉ DE Alencar, que aliás foi seu contemporâneo sob as Arcadas franciscanas, turma de 1846-1850.

Na Faculdade de Direito, portanto, e na garoenta Paulicéia de sobradões coloniais e de aprazíveis arredores pontilhados de chácaras, foi encontrar inspiração para escrever Rosaura, a Engeitada. Uma história em que transparece a prosápia (nem sempre justificada) dos velhos paulistas, dando origem a um drama familiar enredado nas teias da escravidão, e em que estudantes e bacharéis tomam parte saliente, contribuindo para o desfecho feliz. Três dos personagens correspondem à trindade poética famosa nas crônicas do romantismo brasileiro: 
Belmiro é o próprio Bernardo Guimarães, Azevedo é Àlvares de Azevedo, e Aurelio, o mineiro Aureliano Lessa.

O capítulo I do romance tem por título Uma Cena entre Estudantes de S. Paulo e passa-se numa república, ano de 1845. $\mathrm{E}$ dele este trecho:

"Ainda então a cidade de S. Paulo conservava certos laivos de sua primitiva simplicidade, e posto que fosse já, relativamente à época, uma cidade assaz populosa, e o núcleo de um grande movimento intelectual, parecia respirar-se ali ainda a aura tradicional dos tempos de Amador Bueno.

"A classe acadêmica, harmonizando-se com o meio em que vivia, passava vida simples, folgazã e descuidosa, ainda mais do que é ordinário entre essa extravagante variedade do gênero humano. Divididos em grupos, os estudantes se derramavam por todos os bairros da cidade, e chamavam-se REPƯBLICAS, como até hoje, as casas ocupadas por esses grupos, e onde viviam na mais admirável igualdade e fraternidade. Nessa época havia entre os estudantes um certo espírito de classe tão fortemente pronunciado, que formava deles uma corporação, não só respeitada, como temida dos FUTRICAS, nome que se dava a todo cidadão estranho ao corpo acadêmico."

Outro capítulo, o IX, intitulado Conspiração, transcorre no próprio recinto da Academia, com os estudantes dialogando e tramando das suas.

$\mathrm{E}$ assim, pelo romance adentro, vão despontando os usos e costumes estudantis: os passeios pelos arrabaldes; as visitas às chácaras no tempo das jabuticabas; os colóquios provocativos e estimulantes entre os rapazes; as pândegas ; os namoros ("ora, o corpo acadêmico era justamente um viveiro de noivos" "um estudante sinceramente enamorado; coisa rara!") ; a influência dos "correspondentes", controlando as finanças dos moços de outras cidades ou províncias; acadêmicos "que, por escassez de meios ou por qualquer outro motivo", moravam em companhia dos frades em conventos; o conceito nem sempre favorável que deles faziam os paulistanos ("Qual bom moço! $E$ muito estúrdio como todos os seus companheiros... Basta ser estudante"); a presença das decaídas, "prontas a armar 
laço à bolsa dos estudantes", com a observação: "Em toda parte, onde há academia, universidade, ou coisa que o valha, há sempre numerosa cáfila de moços ricos, pródigos e libertinos, que não hesitam em sangrar consideravelmente a bolsa paterna em benefício das cantoneiras"; e, como final, os remoques contra a própria escola: "- Não me fales em atos, nem estudos, nem me faças lembrar da Academia (...) Diga-me, de que nos serve vir aqui estudar o direito, o dever e a justiça, se eles não são e nunca serão respeitados nem executados? (...) maldita ciência, que só existe nos livros e nos códigos, como pura irrisão aos direitos da humanidade (...)".

\section{José de Alencar}

2 - Em 1855, a Academia de Direito de São Paulo completou 27 anos de funcionamento. Por esse tempo, José DE ALENCAR, um jovem bacharel de 26 anos, ali formado, procurava ganhar a vida no Rio de Janeiro, advogando e redigindo, para o Correio Mercantil, folhetins sob o título de Ao Correr da Pena. No folhetim de 3 de junho de 1855 revelou estado de espírito da época, discreteando, com realismo, sem receio de ferir outros da sua grei :

"Atualmente todo o mundo entende que seu filho deve ser negociante ou empregado público: e, tudo quanto não for isto é um desgosto para a família. Quanto à classe rica e abastada, esta não quer outra coisa que não seja o sonoro título de DouToR.

"Doutor atualmente equivale ao mesmo que fidalgo nos tempos do feudalismo. É um grau, um distintivo, um título, uma profissão, um estado.

"No tempo da revolução, os fidalgos, os condes, marqueses e barões emigraram e fizeram-se torneiros, sapateiros, pintores e mestres de meninos.

"É provável que daqui a dez anos, com a fertilidade espantosa das nossas academias, o mesmo venha a suceder aos doutores.

"Tudo isto, porém, parte de um grande erro. Todas as profissões encerram um grande princípio de utilidade social; todas, portanto, são iguais, são nobres, são elevadas, conforme a perfeição a que chegam ( . . ) o homem é que faz a sua profissão; a sua inteligência é que a eleva; a sua honestidade é que a enobrece". 


\section{Luis Gama}

3 - LUIS GAMA, o negro abolicionista, não chegou a estudar nas Arcadas franciscanas. Mas como advogado provisionado, defensor de causas impossíveis, desfrutou de largo conceito em São Paulo, graças ao seu talento e ao seu ardor. Ademais, amigo de estudantes, bacharéis e professores, que lhe admiravam o espírito vivaz, e a coragem, o desassombro das atitudes.

Baiano, filho de um fidalgo malandro e de uma preta escrava (na poesia Minha Mãe confessou ter sido a mãe uma cativa), sofreu o vexame de ser vendido na terra natal pelo próprio pai - como escravo!

Nessa humilde condição humana e social veio em 1840 parar em São Paulo, terra onde se redimiu e passou a redimir os irmãos da sua cor.

Morando na Paulicéia, teria de conviver com acadêmicos de direito e preparatorianos. Com um destes, ANTONIo RoDRIGUES DO PRADO JÚNIOR, bacharel em 1858, aprendeu as primeiras letras. Trabalhou depois como copista de cartório e amanuense de repartições, tomando gosto pelos assuntos forenses.

Conta Raimundo De Menezes no seu Dicionário que Luis GaMA pensou em ingressar no Curso Jurídico, mas desistiu ao enfrentar graçolas e malevolências. Não teria sido por motivos raciais, antes pelo estouvamento e rebeldia daquele negro já liberto, que se recusava a aceitar de cabeça baixa as mentiras e basófias da sociedade e... dos acadêmicos.

Escrevendo no Álbum de um amigo, denunciou-se:
"Ciências e letras
"Ouvindo o conselho
Não são para ti;
Da minha razão,
Pretinho da costa
Calei o impulso
Não é gente aqui...
Do meu coração".

Impertérrito paladino dos escravos - nos tribunais, na imprensa, na vida prática - a sua fama se espalhou, provocando de um lado bênçãos e simpatias, e de outro, entre os escravistas, rancores e apreensões.

Do desprezo, que o atingia, vingava-se mofando dos ridículos e mazelas que pela frente topava. Observador de primeira ordem, e dispondo de um ritmo fácil, satirizou em 
versos pessoas, costumes e instituições da velha Paulicéia. 0 poeta tinha o seu atrevimento, mas sabia quem e o que ferir. Chamou-se a si próprio de ORFEU DE CARAPINHA, repetindo expressão usada por BoCAGE num soneto caústico. Não escaparam à sua sanha nem a Academia, nem a Justiça, setores onde pelejavam os seus melhores amigos.

Nas Primeiras Trovas Burlescas, obra editada em 1859 em São Paulo, com dedicatória "A seu Protetor e Amigo o Ilmo. e Exmo. Sr. Desembargador Dr. F. M. S. Furtado de Mendonça, Decano da Faculdade de Direito da Cidade de S. Paulo" etc., lêem-se estes versos significativos:

"Se estudante que vive à barba longa

Excedendo, no grito, uma araponga,

Braveja contra o FERO DESPOTISMO,

No Letes sepultando o servilismo;

$\mathrm{E}$ depois, quando chega a ser doutor,

Se transforma em sediço adulador;

Permuta a consciência por dinheiro,

E se faz, do Governo, fraldiqueiro:

Não te espantes, Leitor, desta mudança,

São milagres da Deusa da pitança."

"É doutor em ciências sociais,

Conhece toda casta de animais;

Em direito, suplanta o SAvigNY,

Mormente quando toma a - PARATI;

$\mathrm{E}$ nos fastos da gran filosofia

Diz tais coisas que as carnes arripia!

"Correu, em peso, a sábia Academia,

Para ver o planeta que luzia;

Também veio a Polícia, a Medicina,

Discutir tanta asneira em sabatina!

Miraram de alto a baixo o sacripante

$\mathrm{E}$ vendo que o maroto era pedante,

$\mathrm{Na}$ barca de Caronte o encaixaram,

Prá casa dos orates o mandaram."

"Se deslustram honrosos pergaminhos

Patetas que nem servem pra meirinhos,

$\mathrm{E}$ que sendo formados Bacharéis,

Sabem menos do que pêcos bedeis,

Não te espantes, ó Leitor, da novidade,

Pois que tudo no Brasil é raridade! 
"Se temos majestosas Faculdades, Onde imperam egregias potestades, $\mathrm{E}$, apesar das luzes dos mentores, Os burregos também saem Doutores."

"Se a justiça, por ter olhos vendados, E vendida, por certos magistrados, Que o pudor aferrando na gaveta, Sustentam - que o Direito é uma pêta; $\mathrm{E}$ si os altos poderes sociais

Toleram estas cenas imorais;

E que o sábio no Brasil só quer lambança

Onde possa empantufar a larga pança!

"Não tolero o magistrado, Que do brio descuidado, Vende a lei, trái a justiça - Faz a todos injustiça -

Com rigor deprime o pobre, Presta abrigo ao rico, ao nobre, $\mathrm{E}$ só acha horrendo crime No mendigo, que deprime.

- Neste dou com dupla força,

Té que a manha perca ou torça".

\section{Visconde de Taunay}

4 - TAunaY, Visconde de Taunay... Haverá na história da literatura brasileira, ou nas crônicas do nosso Exército, figura mais simpática e valorosa do que esse fidalgo das letras e das armas?

Raros, como ele, souberam traduzir, em frases que têm o colorido próprio de um pintor, as cenas autênticas do sertão de outrora, em histórias e narrativas válidas para os séculos. $\mathrm{E}$ nenhum, como esse descendente de militares franceses, conseguiu descrever, com tanta veracidade e comoção, os lancinantes episódios da cruenta guerra contra os paraguaios. Muito lhe deve a Nação pelo lastro de poesia e ingenuidade (Inocência), de rude verdade marcial (A Retirada da Laguna) e de elegante sinceridade pessoal (Memórias), com que enriqueceu, em livros, as genuínas tradições do Império. 
Diplomado pelo Colégio de Pedro II, tendo recebido o seu prêmio das próprias mãos do Imperador; pianista e desenhista de aprendizagem no lar; o maior anelo, porém, do adolescente ALFREDO D'ESCRAGNOLLE TAUNAY era matricular-se no Curso Jurídico paulopolitano. Mas, conforme narrou na segunda parte das suas "Memórias", "na dificuldade pecuniária em que talvez se vissem meus bons pais de me mandarem estudar direito em S. Paulo, como era ardente desejo meu" (grifo nosso), aceitou seguir a carreira das armas, assentando praça no Exército e cursando engenharia na Escola Militar da Praia Vermelha. Era o destino!

Em abril de 1865, como "ajudante da comissão de engenheiros junto às forças destinadas a Mato Grosso", desembarcou em Santos, para dali seguir rumo às fronteiras do Paraguai, por terra ... Não seria nunca um acadêmico de direito, mas chegara o momento de ir conhecer de perto a Heidelberg dos campos de Piratininga. Já ao subir a serra, em boa diligência, a sua alma de paisagista se deslumbrou com a amplidão dos quadros naturais, e o seu espírito aventureiro com as originais peripécias da jornada. Anos depois, escreveria: "Nas histórias dos estudantes de São Paulo é célebre essa serra de Cubatão".

Cerca de uma semana se demorou na Paulicéia. Um ambiente de entusiasmo guerreiro predominava na cidade. Alegre, juvenil, TaUnay teve tempo para passeios e visitas. Não deixou também de ver o velho casarão das leis no Largo de São Francisco. Todavia, ocorreu num salão particular o brilhante sucesso evocado nas suas Memórias:

"No dia 9 de abril, os estudantes da Faculdade de São Paulo ofereceram à oficialidade da expedição uma espécie de "copo-d'água", à noutinha, porém, o que nos fez supor arremêdo de grande banquete e foi causa para muitos de legítima decepção.

"Discursos não faltaram. O orador oficial da comissão organizadora daquela manifestação fez longo e gongórico discurso, a que respondeu o coronel Drago com voz muito fanhosa, desenrolando meia dúzia de lugares comuns e sediças chapas.

"Depois, outro estudante proferiu palavras entusiásticas e menos estudadas e também por isso credoras do aplauso que as acolheu.

"Deploravelmente lhe respondeu o major Palha, magra figura, espécie de Dom Quixote. 
Animei-me então e tirei do bolso umas palavrinhas que à pressa rabiscara de dia, sem levar contudo intenção firmada de as pronunciar. O que li causou impressão.

"Invertendo a sentença de CícERo Cedant Arma Togae, fiz algumas referências à guerra que se iniciava e causava tão profundo abalo a toda a sociedade brasileira, dando assim indicação da importância daquele fato e das suas conseqüências para o Brasil e toda a América do Sul.

"Terminei de modo a eletrizar todo o auditório, que me cobriu de palmas e vivas. "Senhores! exclamei arroubadamente, com os copos de champagne em mão, prometemos, nós, vossos convivas, defender, com os copos da espada em punho e a todo o transe, a dignidade e a honra da Nação brasileira!".

"Foi o efeito imenso, quer pelo tom, quer pelas circunstâncias; e, largos anos depois, ainda nesse rapto me falaram várias pessoas presentes".

Curioso é que, escrevendo as suas reminiscências tantos anos depois desses fatos, da sua pena brotassem pelo menos duas expressões do ambiente acadêmico da época: calourismo, e "pregar hipótese".

Terminada a guerra, TAUNAY ainda prestou serviços ao País como deputado, senador, e Presidente das Províncias de Santa Catarina e do Paraná. Teve, portanto de conviver, lidar e lutar com bacharéis por anos a fio. Por isso, com profundo conhecimento de causa, pôde sentenciar nas suas Memórias, p. 231: "bacharel em ciências jurídicas, o grande diploma para tudo, para todas as posições e pretensões, naquele tempo em que imperava o BACHARELISMo com a máxima pujança".

E noutro passo da mesma obra (p. 94), referiu-se ao "fatal 15 de novembro de 1889, em que o militarismo suplantou a BACHARELOCRACIA".

\section{Artur de Oliveira}

5 - ARTUR DE OLIVEIRA, gaúcho, patrono da cadeira n. ${ }^{\circ}$ 3 da Academia Brasileira de Letras, teve um temperamento irrequieto, oscilando entre crises religiosas e um viver boêmio 
e dissipado, tanto no Rio de Janeiro quanto na Europa. Talento brilhante, mas dispersivo, foi bem o Saco de Espantos com que - batizou MACHADo DE AsSIS. Adolescente ainda, foi aluno interno do celebérrimo Colégio do Caraça, isolado do mundo, nas asperezas longínqüas de uma serra mineira. Lá, dentro do colégio orientado pelos padres Lazaristas, rígida disciplina e instrução a valer, estimuladas por intensas práticas religiosas. Pretendia o jovem Artur estudar direito, bacharelar-se. Em cartas maneirosas, escritas para o pai do Colégio do Caraça, ano de 1869, manifestou as suas opiniões, revelando o que naquele ambiente, influenciado pelos padres, se pensava a respeito da Academia paulistana:

"(...) devo-me ir daqui no fim do ano letivo, a fim de acabar nesses seis meses os preparatórios em Pernambuco, para matricular-me em sua bem conceituada Academia. Única por assim dizer do Brasil, porquanto S. Paulo não passa de um foco de perdições, do centro da heresia, pois que de há muito que o Protestantismo lá entrou com os autores de certas obras do curso jurídico". (Caraça, 26-1-1869).

"Os preparatórios que preciso estudar são: Aritmética e Geometria, o que farei com a graça e o socorro de Deus em Pernambuco, pois que a ter de estudar Direito, aí é que devo, não só pelo ponto de vista da cidade, como da Academia, que é segundo a expressão do muito Revdo. Padre Domingos Musci, a católica Academia. Em São Paulo professam-se doutrinas errôneas, adotam-se compêndios condenados pela Santa Sé". (Caraça, 9-5-1869).

\section{Júlio Ribeiro}

6 - A ação do romance $A$ Carne, de Júlio RiBeiro, decorre na Província de São Paulo, ano de 1887, ainda em tempos da escravidão e pouco antes da República. Já na primeira página aparece um personagem formado em direito, o dr. Lopes Matoso. Esse doutor é o pai de Lenita, a inverossímil heroína da história. Lenita, intelectual de saias compridas na Capital, transforma-se numa fazenda do interior em mulher e ninfa.

Recebida com reservas, a obra, filiada ao naturalismo, não convence nem o público, nem a crítica. O título, provo- 
cador. O entrecho, cheirando a escândalo. Provoca até virulenta polêmica, com uma das partes falando em "carniça", e a outra redarguindo com o epíteto "urubu". Apenas um mérito ninguém lhe neg.ou: muito bem escrita.

Informa RAIMUNDo DE MENEZES que o jornalista e gramático JÚlio RIBEIRo foi, em data posterior a 1865, professor no Curso Anexo à Faculdade de Direito o que talvez explique o seu vago interesse pela Academia. Nas páginas de $A$ Carne, capítulo XVIII, introduziu carta escrita em São Paulo por Lenita dando notícias, em tom algo petulante ou pretensioso para uma mulher brasileira dos anos do Império, das novidades da Paulicéia. Entre elas, esta:

"O antigo, famoso largo de São Francisco, está que é um brinco.

"A Academia foi reformada.

“Talvez eu não tenha razão; mas o caso é que eu a preferia exteriormente como ela era outrora. Tinha pelo menos o mérito de representar o gosto arquitetônico dos religiosos que dirigiram a colonização do Brasil. Hoje não representa coisa nenhuma, tem uma aparência limpa, mas desgraciosa e até caturra."

A nova fisionomia da velha escola, anotada pela heroína, correspondia à substancial (e necessária) reforma promovida em 1883-1884 pelo diretor Dr. André Augusto de Pádua Fleury.

\section{Brasílio Machado}

7 - Agitação de idéias e comoção popular foram as tônicas que antecederam e se seguiram à proclamação da República, espraiando-se em ondas convulsas pelo país. Nesse período de fermentação social, com os positivistas, republicanos e militares campeando, poucos foram os que souberam resistir à pressão das idéias e dos fatos, mantendo atitudes coerentes.

No âmbito da Faculdade de Direito, um lente pelo menos viu-se sacrificado à indisciplina da época. Foi ele o velho professor de Direito Civil dr. Francisco Justino Gonçalves DE ANDRADE, jubilado em 1890 por ordem do Governo Provisório, após haver enfrentado a petulância de grupos estudantis. Outro, o intemerato dr. José MARIA CoRREIA DE SÁ e BenEviDES, católico e monarquista "par droit de conquête et de nais- 
sance", continuou do alto de sua cátedra a expender os mesmos conceitos que sempre defendera, zurzindo os novos modismos com o látego da sua lógica implacável. Incompatibilizado, viu-se constrangido a pedir jubilação, que lhe foi concedida ainda em 1890.

A um outro lente mais moço, dr. BRAsílio Augusto MACHADO DE OLIVEIRA, homem de fé e de convicções, católico no lar e na vida pública, competiu a ingente tarefa de apontar aos moços daquela geração o caminho verdadeiro dos valores permanentes, rejeitando ao mesmo tempo a incerteza das soluções transitórias e das meias verdades apregoadas como realidades definitivas. Teve ele de arrostar incompreensões, polêmicas e vitupérios. A tudo resistiu, cônscio da dignidade da sua missão, opondo aos desafetos a segurança das idéias, a opulência da cultura jurídica e literária, o fascínio da oratória.

Catedrático de Direito Comercial em 1891, encontrou nos alunos recepção fria e relutante, substituída a pouco e pouco por entusiasmo e admiração, tais as qualidades do mestre. Já no ano seguinte, 1892, foi convidado a paraninfar a turma que se formava. Em 1893, na data de 11 de Agosto, pronunciou memorável discurso durante a festa comemorativa da criação dos cursos jurídicos. Oportuna se apresentava a ocasião para reiterar, à face de todos, o primado do direito, e para advertir que somente na mocidade estudiosa residia o futuro da Pátria. Pertencem a essa corajosa oração os excertos que se vão ler:

"A Faculdade de Direito de São Paulo, aqui representada por mestres e discípulos, em toda a sua poderosa unidade de instituição social, veio comemorar no meio de vós a lei de sua criação.

"Interrompendo o silêncio com que, em sua indiferença estranha, o povo se vai acostumando a distanciar da recordação das coisas vivas, a memória das coisas mortas, como se não devêssemos nas tradições de nossa história ganhar alento para afrontar os perigos de hoje e eliminar as indecisões de amanhã, - a reunião desta hora bem pode recordar aquele mármore mutilado, em que u'a mulher, representação de pátria piedosa, debruçada arreda com as mãos o musgo das ruínas, procurando soletrar no chão mortuário o nome quase extinto do seu glorioso filho.

"As comemorações das grandes conquistas sociais são essas mensageiras de luz. De geração em 
geração, como de montanha em montanha, elas passam publicando as tradições que frutificam às esperanças que florescem.

"E que grandeza, senhores, em nossa vocação!

"E das Faculdades superiores que sai o orador para na tribuna, cheia da majestade de seu talento, domesticar pelo impulso irresistível de sua palavra as irrequietas multidões, e subjugá-las, envoltas nas cadeias sonoras da eloqüência. É nas Faculdades superiores que o legislador aprende a ciência quase divina de refrear, pela coerção do direito, essa movimentação incessante e sempre nova da liberdade humana, presa dentro do organismo social. E nas Faculdades superiores que o mestre sobe até às regiões mais árduas da ciência, para arrancar o segredo das leis que governam a natureza inteira e os mundos siderais, como domina o mais sutil dos movimentos das células. É nas Faculdades superiores, que palpita a grande alma nacional, a mocidade, em cujos lábios cantam todas as esperanças, em cujas esperanças floresce todo o futuro da pátria!

"Que conquista generosa se fez lei, antes de ser propaganda dos nossos centros acadêmicos? E de ontem a emancipação dos escravos; é de ontem, ou por outra, começou de ontem a instituição da República. E esses dois fatos (. .) que foram eles, senão fugitiva aspiração, que de um e de outro ponto do país surgia, como raio indeciso de uma luz longínqua, antes que a alma acadêmica se abrisse, como um horizonte puro de nuvens, às claridades de uma grande aurora?

"Deixai que murmurem as vozes subterrâneas da malícia, da inveja, que chegam a lobrigar, em nossas Faculdades, uma fábrica cansada de bacharéis inúteis! A ação de nosso trabalho é lenta e silenciosa, por isso mesmo que é eficaz e duradoura.

"O pé dos maldizentes não pode abafar a lembrança de nossas tradições.

"O que é mister é não esmorecer na missão de responsabilidades que a nossa vocação social impõe. As nossas Faculdades não devem ser relicários de recordações. Entranhas estéreis não são entranhas de mãe. 


\begin{abstract}
"A nossa situação, abalada como foi do rumo do direito, nos convida a uma dedicação sem limites. Aos problemas que a assaltam, às indecisões que a perseguem, aos erros que a aniquilam, à força que a arrasta, oponhamos a alma da mocidade, para quem o direito não se fez do aço das espadas, mas do ouro da justiça, para quem a pátria grande, feliz e próspera, é a suprema aspiração de todos".
\end{abstract}

\title{
Rui Barbosa e a Oração aos Moços
}

8 - 29 de março de 1921. Na Faculdade de Direito, sessão solene. Levanta-se o Prof. Dr. REInaldo Porchat e lê, para os rapazes da turma de 1920, que colavam grau, o discurso do paraninfo.

Mas quem era o paraninfo? Ninguém mais, ninguém menos, do que Rui Barbosa. Adoentado, em Petrópolis, Rui ali escrevera, "entre acessos febris", quase todas aquelas páginas, enviadas a São Paulo.

E uma a uma, como gotas de sabedoria, as surpreendentes palavras de RUI BARBOSA (bacharel da turma de 1870) ecoaram pelas Arcadas, revivendo, confessando, despertando brios. Eram "cinquenta anos de consagração ao direito", que vinham receber, "no templo do seu ensino em São Paulo", a homenagem dos jovens, que o polígrafo, comovido, chamou de "filhos meus".

Quem não conhece a Oração aos Moços? Pequeno livro, que é a súmula de um homem de gênio, de caráter e de coração. De um homem de múltiplos talentos, reconhecidos e acatados internacionalmente. Homem que não traiu os seus ideais de jovem e serviu à Justiça e à Pátria como ninguém. Que foi ardoroso, combativo, até violento, mas fiel aos sentimentos cristãos hauridos no lar.

Pois foi esse bacharel, então com 71 anos de idade, esse sábio, que veio afirmar à perplexa geração que o convidara para padrinho o que vai nestes fragmentos da Oração aos Moços:

"Estudante sou. Nada mais. Mau sabedor, fraco jurista, mesquinho advogado, pouco mais sei do que saber estudar, saber como se estuda, e saber que tenho estudado." 
"Ora, senhores bacharelandos, pesai bem que vos ides consagrar à "lei" (. . .)".

"Magistrados ou advogados sereis. São duas carreiras quase sagradas, inseparáveis uma da outra, e, tanto uma como a outra, imensas nas dificuldades, responsabilidades e utilidades."

"É à magistratura que vos ides votar? Elegeis, então, a mais eminente das profissões, a que um homem se pode entregar neste mundo.

"Não tive a honra de ser magistrado. Advogado sou, há cinquenta anos, e, já agora, morrerei advogado."

"Na missão do advogado também se desenvolve uma espécie de magistratura. As duas se entrelaçam, diversas nas funções, mas idênticas no objeto e na resultante: a justiça. Com o advogado, justiça militante. Justiça imperante, no magistrado."

"Legalidade e liberdade são as tábuas da vocação do advogado. Nessas se encerra, para ele, a síntese de todos os mandamentos."

Para terminar, este grão de sabedoria:

"Por derradeiro, amigos de minha alma, por derradeiro, a última, a melhor lição da minha experiência. De quanto no mundo tenho visto, o resumo se abrange nestas cinco palavras:

"Não há justiça, onde não haja Deus."

II. Informações Coligidas pelo Marechal Daniel Pedro Müller. Transcrição da Tabela n.o 20 , referente às Atividades Acadêmicas de 1836 .

Em 1835 instalou-se em São Paulo a primeira Assembléia Legislativa Provincial. Uma de suas iniciativas mais proveitosas foi ordenar um levantamento estatístico de toda a Província. A comissão foi entregue à alta competência do engenheiro militar Marechal Daniel Pedro Müller, o mesmo a quem se devia a erecção na Capital, em 1814, da famosa pirâmide do Piques.

Os trabalhos de organização e redação da infinidade de dados e notícias coletados, referentes ao ano de 1836, resultaram no "Ensaio Dum Quadro Estatístico da Província de 
São Paulo", que consta haver sido o primeiro livro impresso na Capital paulista.

O Ensaio elaborado pelo Marechal Müller constituiu, para a época, apreciável fonte de estudos e esclarecimentos, extremamente úteis para os administradores. Mas teve também o mérito de aglutinar e fixar para a posteridade um sem número de pormenores, que sem ele talvez ficassem dispersos ou perdidos. Representa, ainda hoje, indeclinável ponto de referência, sempre compulsado pelos estudiosos do passado.

No capítulo da Educaçã்o e Instrução Pública, contém o "Ensaio" precisas informações sobre o incipiente Curso Jurídico da Paulicéia, instalado no antigo Convento dos frades franciscanos. Formam elas a Tabela elucidativa N. ${ }^{\circ} 20$, aqui reproduzida.

Difícil de consultar, pela sua raridade como obra do Século XIX, o "Ensaio" do Marechal Müller viu-se reeditado em 1923, graças à diligência de um bacharel historiador formado em São Paulo na turma de 1891, o então Presidente do Estado Washington Luis Pereira de Sousa.

\section{Tabella N.0 20.}

Quadro demonstrativo das Cadeiras da Academia Juridica de $S$. Paulo, quaes os Lentes que as regem, materias que se ensinam, e por que Compendios, Cadeira que é necessario crear-se, epocha da criação da Academia, quando foi aberta, que Directores tem tido, vice-Directores, que numero de Escollares se tem matriculado, formado, e doutorado até o presente; Bibliotheca, numero de livros que possue.

1. ${ }^{\circ}$ Anno. Cadeira: uma unica. Nome do Lente Proprietario: Dr. José Maria de Avellar Brotero. Materias que se ensinam: Direito Natural e Publico, analyse da Constituição do Imperio - Compendio: Perreau.

2. $\quad$ AnNo. Duas cadeiras. - $10^{\mathrm{a}}$ Cadeira. Nome do Lente Proprietario: Dr. Manoel Joaquim do Amaral Gurgel. Materias que se ensinam: Continuação das materias do 1. ${ }^{\circ}$ anno; Direito das Gentes e Diplomacia. Compendios: Vattel, e Martens, manual de Diplomacia. - 2. ${ }^{\mathrm{a}}$ CADEIRA. Nome do Lente Proprietário: Dr. Anacleto José Ribeiro Coutinho. - Materia que se ensina: Direito $\mathrm{Pu}-$ blico Ecclesiastico. Compendio: Gmeiner. 
3. ${ }^{\circ}$ Anno. Duas cadeiras. - $10^{\mathrm{a}}$ CADEIRA. Nome $d o$ Lente Proprietario: Dr. Prudencio Geraldes Tavares Cabral. - Materia que se ensina: Direito Civil Patrio. Compendio: Pascoal José de Mello Freire. - 2. ${ }^{\mathrm{a}} \mathrm{CA}$ DEIRA. Nome do Lente Proprietário: Dr. Manoel Dias de Toledo. - Materia que se ensina: Direito Patrio Criminal. Compendios: Codigos Criminal e do Processo.

4. ${ }^{\circ}$ Anno. Duas cadeiras. $1 .^{\mathrm{a}}$ CADEIRA. - Nome do Lente Proprietario: Dr. Vicente Pires da Motta. Materia que se ensina: Continuação do Direito Patrio Civil. Compendio: Codigo Mello Freire. - 2. ${ }^{\mathrm{a}}$ CadeIRA. Nome do Lente Proprietario: Dr. Clemente Falcão de Souza. Materias que se ensinam: Direito Maritimo e Mercantil. Compendios: Azuni, e Codigo do Comercio Francez.

5. ${ }^{\circ}$ Anno. Duas cadeiras. $1 .^{\mathrm{a}}$ CADEIRA. Nome do Lente Proprietario: Dr. Carlos Carneiro de Campos. Materia que se ensina: Economia Politica. Compendio: Cathecismo de Say. - 2. ${ }^{\mathrm{a}}$ CadeIRA. Nome do Lente Proprietario: Dr. Antonio Maria de Moura. Materias que se ensinam: Theoria e Pratica do Processo. Compendio: Mello Freire. Nomes dos Lentes Substitutos: Dr. José Ignacio Silveira da Motta, Dr. Francisco José Ferreira Baptista, Dr. Francisco Bernardino Ribeiro, Dr. Joaquim Ignacio Ramalho, Dr. João Crispiniano Soares.

Estes lentes substitutos vencem $800 \$ 000$ de ordenado annual; tendo os lentes proprietarios $1: 200 \$ 000$.

Observaçoens: É necessario crear-se por Lei uma cadeira de Direito Romano, e esta deve ser ensinada no $10^{\circ}$ anno. Foi creada esta Academia pela Lei de 11 de Agosto de 1827; serviram de Estatutos interinos o do Visconde da Cachoeira até que vieram os Estatutos provisorios da Assemblea Geral Legislativa de 7 de Novembro de 1831. Foi aberta solemnemente pelo primeiro lente Dr. José Maria de Avellar Brotero no dia 1. ${ }^{\circ}$ de Março de 1828 , e explicou a primeira lição a 10 do dicto mez. Tem tido tres Directores, o 1. $0^{\circ}$ Tenente General José Arouche de Toledo Rendon, o 2. ${ }^{\circ}$ Dr. Carlos Carneiro de Campos, o 3. ${ }^{\circ}$ Dr. José da Costa Carvalho; servindo nas faltas de vice-Director os Drs. Lentes mais antigos da Academia, Moira, Cabral, Falcão, e presentemente o Dr. Brotero pelo seu direito de antiguidade depois de reconhecida pelo Aviso de 30 de Setembro do corrente anno. Matricularam-se no anno de 1828 , 33 estudantes, em 1829, 73, em 1830, 99, em 1831, 64, em 1832, 37 , em 1833, 38, em 1834, 28, em 1835, 43, 1836, 4, sommando 
tudo 419. Tem-se formado Bachareis 253, Doutoraram-se 19. Estam empregados como Lentes, e substitutos 9 Doutores formados n'esta Academia.

Possue esta Academia uma Bibliotheca com seis mil e quarenta e cinco volumes; entrando n'estes volumes algumas obras antigas de valor, e que estam ainda em bom estado; faltam porem todas as obras modernas, mesmo pertencentes á classe de Jurisprudencia. Sobre Bellas Lettras quasi nada possue. A Encyclopedia existe truncada. No tempo do Director Carneiro de Campos vieram - The Edimburghreview or critical journal N. ${ }^{\circ} 1$. Outubro de 1802 até N. ${ }^{\circ} 125$ Outubro de 1835. - The Quarterley review N. ${ }^{\circ} 1$. Fevereiro de $1809 \mathrm{~N} .^{\circ}$ 109 Dezembro de 1835 - The Westminster review N. ${ }^{\circ} 1$. Janeiro de 1824 a N. ${ }^{\circ} 49$ Outubro de 1835 - Encyclopedie populaire Vol. $1 .^{\circ}$ a 125 - Jornal do Instituto Historico de Outubro de 1834 até Agosto de 1835 - Jornal dos Conhecimentos uteis do N. ${ }^{\circ} 1$. Outubro de 1831 até Dezembro de 1835 - Encyclopedia dos Conhecimentos uteis N. ${ }^{\circ} 1$. Outubro de 1822 até N. ${ }^{\circ} 48$ Setembro de 1834 desde a letra - A - até - C A. - Revue Botanique de Janeiro de 1833 até Dezembro de 1835 - Revue Encyclopedique de Janeiro de 1833 a 1834 - Revue de deux mondes Outubro de 1834 a Janeiro de 1835.

Secretaria da Academia Juridica de S. Paulo, 16 de Dezembro de 1836. - Ildefonso Xavier Ferreira, Official Guarda Livros servindo de Secretario o fez.

Quadro demonstrativo das Aulas de preparatorios da Academia Juridica de S. Paulo, numero de alumnos nos annos de 1834 e 1836, (extrahido dos unicos documentos que existem na Secretaria) nomes dos Professores que regem as Cadeiras, seus Ordenados.

LATIM. Nome do professor proprietario: vaga. Ordenado que vence: $480 \$ 000$. Numero de alumnos em 1834: - 0. Numero de alumnos em 1836: 49.

INGLEZ. Nome do professor proprietario: Dr. José Thomaz de Aquino. Ordenado que vence: 400\$000. Numero de alumnos em 1834: 0 - Numero de alumnos em 1836: 18.

Francez. Nome do professor proprietario: Dr. José Thomaz de Aquino. Ordenado que vence: $400 \$ 000$. Numero de alumnos em 1834: 28 - Numero de alumnos em 1836: 22 - Diminuição em 1836: 6.

RETHORICA. Nome do professor proprietario: Fidelis Alves Sigmaringo de Moraes. Ordenado que vence: $440 \$ 000$. 
Numero de alumnos em 1834: 9. Numero de alumnos em 1836: 16. Excesso em 1836: 7 .

Philosophia Racional E MoRal: Nome do professor proprietario: Bacharel Manoel José Chaves. Ordenado que vence: 600\$000. Número de alumnos em 1834: 73. Número de alumnos em 1836: 28. Diminuição em 1836: 45.

Geometria. Nome do professor proprietario: Francisco Maria Goulart. Ordenado que vence: $600 \$ 000$. Numero de alumnos em 1834: 0. Numero de alumnos em 1836: 18.

HISTORIA E GEOGRAPHIA: Nome do professor proprietario: Julio Frank. Ordenado que vence: $600 \$ 000$. Numero de alumnos em 1834: 38. Numero de alumnos em 1836: 22. Diminuição em 1836: 16.

Substituição DE Philosophia: Nome do professor proprietario: vaga. Ordenado que vence: 150\$000. Numero de alumnos em 1834: 0. Numero de alumnos em 1836: 0 .

DICTA DE LATIM E RETHORICA: Nome do professor proprietario: vaga. Ordenado que vence: 200\$00. Numero de alumnos em 1834: 0. Número de alumnos em 1836: 0. Total: numero de alumnos em 1834: 148; numero de alumnos 1836: 173.

Observaçoens: Estas cadeiras carecem d'um Regulamento economico. Ha grande falta na regularidade dos Ordenados dos Professores, e sua mesquinhez é a causa de estarem vagas por tanto tempo a cadeira de Latim e as Substituiçoens. Por officio de 26 de Novembro do corrente anno pedio-se ao Governo Central mande pôr em concurso as Substituiçoens para todas as cadeiras como estam creadas em Olinda.

Quando appareceu a Lei de 11 de Agosto de 1827 criando as duas Academias Juridicas existiam criadas, como Aulas Provinciaes, as cadeiras de Latim, Rethorica, e Philosophia, e as duas Substituiçoens para estas cadeiras, que foram incorporadas com o mesmo ordenado que tinham á Academia debaixo da inspecção immediata do Director pelo Aviso de 20 de Dezembro de 1828.

Como a Lei de 11 de Agosto de 1827 exigia exames de Francez e Geometria, criaram-se estas cadeiras; e os Estatutos Provisorios de 7 de Novembro de 1831, exigindo ainda mais as de Inglez, Historia e Geographia foram creadas mais estas duas cadeiras, ficando incorporadas n'um só Professor a de Inglez e Francez, pelo Aviso de 4 de Setembro de 1834. 
Secretaria da Academia Juridica de S. Paulo, 16 de Dezembro de 1836. - Ildefonso Xavier Ferreira, Official Guarda Livros, servindo de Secretario o fez. - José Maria de Avellar Brotero, Director interino.

\section{Os Viajantes. Observações e Comentários que Fizeram Sobre a Antiga Faculdade de Direito.}

1 - Em 1834 saiu dos prelos, na cidade do Rio de Janeiro, o "Dicionário Topográfico do Império do Brasil, contendo a descrição de todas as províncias em geral, e particularmente de cada uma de suas cidades, vilas, freguesias, arraiais, e aldeias etc.", elaborado por JosÉ SATURNINO DA COSTA PEREIRA.

Nascido em 1773 na Colônia do Sacramento (outrora domínio português, hoje cidade de Colônia, no Uruguai) e irmão do destemido jornalista HIPólITo José DA COSTA PEREIRA, estudou o autor Matemáticas em Coimbra, foi lente da Escola Militar na Corte, senador do Império por Mato Grosso, Ministro da Guerra em 1837 durante a Regência do Padre Feijó, e membro do Instituto Histórico e Geográfico Brasileiro. Escreveu numerosos trabalhos de fundo didático e científico. Na qualidade de oficial do Corpo de Engenheiros viajou e estudou boa parte do território brasileiro.

o Dicionário Topográfico parece ter sido uma das primeiras obras de interesse nacional a mencionar a Academia de Direito paulistana. Antecedeu de alguns anos a publicação, em 1838, do Ensaio Dum Quadro Estatístico da Província de São Paulo, do Marechal DANIEL PEDRo MüLler, no qual a organização da incipiente Academia vem exposta com todas as minúcias.

José Saturnino da Costa Pereira, no verbete consagrado à Província de São Paulo, exarou estes conceitos sobre a Capital:

"Os subúrbios da Cidade, para qualquer lado que se saia, são mui aprazíveis, com elegantes casas de campo anexas a pomares plantados ordenadamente, oferecendo extensos e lindos golpes de vista. A cidade é abundantíssima de víveres a bom mercado, que produzem os seus contornos (...)".

"Há todas as escolas de instrução primária, e um Curso Jurídico, que confere os graus de Bacharel, e de Doutor, freqüentado por muitos alunos, que ali vão de diferentes Províncias do Império" 
2 - ALCIDE D'ORBIGNY, naturalista francês, visitou São Paulo em data incerta, entre os anos de 1830 e 1833 . Na sua obra clássica Voyage Pittoresque dans les Deux Amériques (Paris, 1836) conta que se demorou uma semana na Capital paulista, percorrendo também os arredores. Muita coisa original observou e registrou. A respeito de instrução, apenas esta generalidade:

"Les paulistes ont en géneral le génie inventif et l'imagination ardente. On fait chez eux des études classiques qui suivent assez bien la progression des idées nouvelles". Nenhuma linha ou palavra sobre a Academia de Direito.

Pouco tempo depois, em 1837, outro francês, FERDINAND DENIS, escritor culto e amigo do Brasil, veio conhecer São Paulo e anotou no seu livro ilustrado Brésil (Paris, 1838) a existência dos três conventos da cidade: dos beneditinos, dos carmelitas descalços e dos franciscanos. A propósito do movimento intelectual, lembrou que desde o governo do Príncipe Regente D. João se cogitara da instalação de uma Universidade, ou no Rio de Janeiro ou em São Paulo. Planos foram apresentados e rejeitados. Por fim, garantiu Ferdinand Denis errando em cheio na data, algo se concretizou:

"En 1826 une école de droit a été fondée à Saint-Paul, et la durée des cours que l'on y doit suivre a eté fixée à cinq ans".

3 - Instalado num velho convento já quase bi-secular, em 1839 contava o Curso Jurídico apenas onze anos de existência; mas não demonstrava sintomas de progresso, tendo diminuido bastante o número de alunos matriculados. Foi quando o visitou um pastor metodista norte-americano, interessado em propagar a Bíblia. Homem justo, cheio de curiosidade e simpatia, o Reverendo DANIEL PARRISH KIDDER publicou, de volta à terra natal, um relato das suas peregrinações pelo Brasil, que se tornou obra clássica.

Viajando do Rio de Janeiro a Santos, num pequeno vapor costeiro, encontrou a bordo um jovem fluminense, que "tinha passado diversos anos em Paris e ia agora matricular-se na Faculdade de Direito de São Paulo". Já na Capital paulista, relacionou-se com a sociedade, freqüentando as melhores famílias e aprendendo-lhes os hábitos. Realizou numerosas excursões pelas circunvizinhanças. Numa delas, demorou-se vários dias numa fazenda no sopé do morro do Jaraguá, cujo pico escalou, podendo lá de cima contemplar imensa e encantadora 
paisagem. A fazendeira viúva se esmerou na hospitalidade e entre a escolhida companhia pôde o Reverendo notar um bacharel em direito, genro dela, e um padre professor da Faculdade de Direito, que ali fazia as vezes de capelão.

De volta à cidade, visitou a Academia, percorrendo-a demoradamente com o diretor em exercício dr. JOSÉ MARIA DE AVELAR BRotero. Na Biblioteca, bem fornecida de volumes, aproveitou o ensejo para oferecer um exemplar da Bíblia traduzido em português. Na dedicatória, que lhe apôs, constava a data: 15 de fevereiro de 1839. Em fevereiro, as aulas estavam fechadas e os estudantes, em férias.

Leiamos, portanto, o que desse período escreveu o amável Reverendo sobre a nova Academia, que curiosamente, em mais de um passo da obra, é citada como Universidade de Direito, ou Universidade de São Paulo:

"A Academia de Direito, ou como é freqüentemente denominada, a Universidade de São Paulo, ocupa o primeiro lugar entre os estabelecimentos de ensino do Império. Tivemos excelente oportunidade de visitá-la, tendo por essa ocasião sido apresentados pelo secretário ao presidente em exercício (sic) Dr. Brotero. Este cavalheiro; cuja esposa é norte-americana, merece respeitosa menção, não só pelo zelo e habilidade com que dirige a instituição, mas, também, como escritor. Publicou um trabalho sobre "Os Princípios da Lei Natural" e um tratado sobre "Presas Marítimas".

"O prédio dos Cursos Jurídicos foi originalmente construído para convento dos frades franciscanos aos quais o governo obrigou abandoná-lo para ser consagrado ao uso mais proveitoso de atualmente. Sendo de construção boa e ampla, com pequenas alterações, foi adatado às necessidades do estabelecimento. As salas de aulas e de preleções ficam no primeiro andar; as dos professores e a biblioteca, no segundo. Essas peças, juntamente com um amplo claustro, constituem todo o estabelecimento, além de duas imensas capelas até hoje devotadas à sua finalidade original. Numa delas vimos algumas pinturas bem bonitas e um enorme andaime onde diversos operários trabalhavam no estuque da arcada principal do teto. Ambas as capelas estavam repletas de imagens e quadros em cores, representando o santo padroeiro." 
A Biblioteca, na revelação de KIDDER, continha sete mil volumes, provenientes de diversas origens e doações: "Não eram muitos os livros sobre direito e belas letras, e, no que toca às ciências, era bem deficiente a livraria. A única compensação para tão lamentáveis lacunas (diz ele com ironia) era um elevado número de livros de teologia ainda não lidos e que certamente jamais o serão. Entre eles, porém, não havia um único exemplar da Bíblia - a fonte de toda a teologia certa - na língua do país, sendo que dificilmente em São Paulo se poderia mencionar outro livro mais raro". Essa observação de KIDDER faz crer que havia na Biblioteca pelo menos uma Bíblia, é claro, provavelmente em latim, mas nenhuma em língua portuguesa.

4 - IDA PFEIFFER, nascida em Viena em 1795, foi a mais famosa "globe-trotter" do século XIX e provavelmente a primeira mulher a completar uma viagem de circunavegação. Pequena de estatura, mas de compleição robusta e temperamento enérgico, teve coragem para sulcar quase todos os mares, desembarcar em portos estranhos de todos os continentes e percorrer o interior, sempre cheio de perigos e ciladas, de numerosos países, alguns ainda semi-selvagens. Tudo isso numa época em que as mulheres viviam confinadas no ambiente doméstico, pouco saíam de casa e raramente viajavam.

Publicou vários livros relatando as peripécias e observações de suas jornadas longínqüas em terras exóticas, bastante apreciados pelos leitores europeus. Um deles, traduzido para o francês, intitulava-se Voyage D'Une Femme Autour Du Monde (3. ${ }^{a}$ edição, Paris, 1865) e granjeou popularidade.

Nos primeiros capítulos dessa obra, dá conta IDA PFEIFFER da sua chegada, em setembro de 1846, ao Rio de Janeiro, onde permaneceu até quase o fim daquele ano, tendo tido oportunidade de presenciar os festejos pelo batismo da Princesa Isabel.

Da Guanabara deveria seguir, num belo veleiro inglês, rumo ao Estreito de Magalhães e daí a Valparaíso, no Chile. Mas o navio, contra a expectativa, aportou em Santos para prover-se de víveres (mais baratos do que no Rio de Janeiro), para descarregar uma encomenda de 200 toneladas de carvão de pedra e levar outra de 6.000 sacas de açúcar.

Algo contrariada com a demora, a senhora PFEIFFer aproveitou o inesperado lazer para efetuar rápida excursão a São Paulo, entre os dias 15 e 18 de dezembro de 1846 .

Ei-la, pois, com mais três companheiros de bordo, todos armados de pistolas, com medo dos negros quilombolas, e mon- 
tados em mulas, a cavalgar pelo movimentado caminho que levava ao Cubatão, cujo rio do mesmo nome atravessaram pela ponte coberta, pagando um bom pedágio.

Fortes emoções provocou neles a áspera subida da serra. Lá de cima gozaram de uma visão extraordinária, com a paisagem se dilatando por vales, planícies, baías e praias remotas. Bem ao fundo, lobrigaram o casario de Santos e mastros de embarcações fundeadas no porto.

Depois, pela frente, um país novo, de terreno ondulante, a espaços recoberto de bosques, aqui e acolá interrompidos por campinas verdolengas. Próximo à Capital apareciam colinas arenosas.

O panorama da cidade ao longe, descansando numa colina, ao entardecer, agradou à senhora PFEIFFER. O desapontamento veio logo após, ao verificar que "elle n'a pas un hôtel ni même une simple auberge où les étrangers puissent trouver à se loger". Depois de várias peripécias conseguiram, usando uma carta de recomendação trazida da Corte, alojar-se em casa de certo alemão solícito, chamado Loskiel. (Talvez JACó LOSKIELL, que em 1860 teve uma confeitaria na antiga Rua do Comércio).

Em um dia e meio procurou IDA PFEIfFER examinar as "curiosidades" de São Paulo. Eram poucas, segundo ela. As suas observações, superficiais, pouco interesse despertam. Achou os edifícios em geral sem gosto e sem estilo. Às igrejas que viu, por dentro e por fora, dedicou a maior indiferença. Estranhou as ruas largas, porém desertas, e o silêncio que reinava na cidade inteira, só importunado pela "musique infernale" das rodas do que ela chamou de "charrette de paysans" e que deviam ser os nossos carros de bois de eixo fixo, tocados por caipiras de pé no chão...

Como outros colegas "globe-trotters", cujos nomes ecoaram por todo o orbe terráqueo, não deixou de incidir, pelo menos uma vez, no clássico equívoco de tomar a parte pelo todo. Marcavam as folhinhas 16 de dezembro e a temperatura na Paulicéia por certo prenunciava o verão que vinha chegando. Pois a senhora PfEIFFer, tendo permanecido menos de 48 horas na Capital, encontrou jeito de emitir um conceito válido para o ano todo: "Le climat de Santo Paulo (sic) est trés-chaud". Logo em seguida, porém, comentou que os paulistanos andavam todos encapotados e que muitas mulheres apareciam pelas ruas envolvidas em largos chales, ou mantilhas. Tanto agasalho num clima quente? É que a forasteira não teve tempo de aprender que em Piratininga as condições 
do solo recoberto de várzeas úmidas, a constância dos ventos, as matas da Cantareira, e outros fatores, ofereciam à cidade noites frias durante as quatro estações e uma temperatura média anual das mais amenas.

A senhora PFEIFFer arribou à Paulicéia em meado de dezembro, encontrando o Curso Jurídico em férias, uma boa parte dos professores descansando em suas chácaras nos arredores da cidade, e os moços estudantes de retorno aos ninhos paternos. Que poderia escrever a respeito? Apenas estas linhas insípidas:

"Santo Paulo (sic) posséde une université; mais les étudiants qui viennent de la campagne ou des villages ont le désagrément de ne trouver personne qui veuille les recevoir. Ils sont forcés de louer des logements, de les meubler et d'avoir un ménage à eux".

Nesse breve comentário, nada mais fez IDA PFEIFFER do que relembrar a sua experiência à procura de hospedagem em São Paulo; mas por outro lado, ao falar em "ménage à eux", indicou o hábito de os estudantes se congregarem em repúblicas.

IDA PFEIFFER parece ter sido, no século XIX, a única viajante escritora a dedicar algumas linhas à Academia de Direito de São Paulo. Depois dela, só no século XX, 1908, apareceu outra mulher, das mais cultas e ilustradas, para visitar a vetusta escola e sobre ela escrever sucinta informação: foi a senhora GINA Lombroso FERRERo.

5 - Coincidência das mais curiosas ocorreu no ano de 1847: enquanto um jovem bacharel em direito norte-americano vinha visitar o Brasil, era apresentado ao Imperador, e se comprazia em escrever para a noiva distante um diário de suas peregrinações, só no século XX tornado público; outro bacharel brasileiro, mais jovem ainda, formado em São Paulo em 1846, percorria os Estados Unidos, entrando em teatros, museus, galerias de arte, bibliotecas, igrejas, universidades, tribunais, penitenciárias, escritórios de advocacia, secretarias de Estado, nos edifícios do Congresso, dos Correios, do Tesouro, e conhecia pessoalmente, na Casa Branca, o Presidente JAMEs KNox PoLK, de tudo tomando apontamentos inteligentes, divulgados quase um século depois, em 1945, por um sobrinho.

A aproximação desses fatos e o cotejo entre as duas personalidades nunca foi feito. A análise dos trabalhos de ambos, podemos adiantar, favorece o brasileiro JoÃo DABNEY DE AVE- 
LAR BROTERo. Este, apesar dos seus 20 anos de idade, revelou-se mais perspicaz, com idéias gerais bem assentadas em amplo lastro cultural, e responsável por observações muito realistas do ambiente social da grande República do Norte, naquele tempo em rápido progresso.

SAMUel GReEne ARNOLD, nascido em Providence, Rhode Island, em 1821 filho de abastado comerciante, formara-se em Direito em 1845 pela bicentenária Universidade de Harvard. Visitara a Europa, a Rússia, a Síria, o Egito, Em 1847 embarcou em Southampton rumo às plagas sul-americanas. No Rio de Janeiro teve ocasião de freqüentar a alta sociedade e de, num baile do Cassino, prosear animadamente, em francês, a respeito de suas viagens, com o Imperador de 22 anos D. Pedro II. Pôde também conhecer o dr. José Antônio Pimenta BueNo (formado em São Paulo, 1832, mais tarde Marquês de São Vicente), que descreveu como um homem pequeno, tendo olhos de lince e muita sutileza diplomática.

Num pequeno vapor, de nome CARLOTA, levou ARNOLD dois dias para chegar a Santos. Ali, na véspera do Natal de 1847, se hospedou em casa do cônsul britânico Mr. Guilherme Whitaker, casado com uma brasileira. O casal tinha ao todo onze filhos. Um deles, que Samuel designou como JoHN, literato e com idéias de se dedicar ao foro, podemos identificar como JoÃo GUILHERME DE AGUIAR WHITAKER, então segundanista na Academia de Direito de São Paulo, pois fez parte da turma de 1846-1850, a mesma de JoSÉ DE ALENCAR.

Chovia a cântaros na Baixada Santista. O mês de dezembro chegava ao seu fim. Bonachão, o ianque soube esperar, e na hora que julgou propícia se pôs a caminho de São Paulo montado numa mula. Tudo inútil. Outros aguaceiros, com raios e trovões, o apanharam entre os mangues e na subida da serra, a ziguezaguear entre "árvores gigantescaș", precipícios, barrancos desmoronados e torrentes, tendo como compensação o canto dos pássaros e o murmúrio de cascatas na floresta virgem. Pousou na metade do caminho. No dia 29 de dezembro prosseguiu viagem, transitando por São Bernardo e pelo pavilhão erguido na colina do Ipiranga para lembrar Pedro I e o gesto da Independência. Por fim lhe apareceu diante dos olhos, ao longe, a perspectiva da Capital, com as torres e cúpulas das igrejas se destacando sobre os telhados dos casarões.

Cansado e moído de andar horas a fio em lombo de mula, ainda perambulou pela cidade sem hotéis, procurando acomodação, o que afinal conseguiu com o inglês Hopkins. Este ho- 
mem era um latoeiro, ignorante, vulgar e dado à embriaguez. Quando não bebia mostrava-se amável; na despedida, nada quis cobrar do moço culto que em sua casa se hospedara.

Apenas dois dias permaneceu SAMUel Greene ARNold na Paulicéia. A cavalo, na companhia de Hopkins, foi ver o Jardim Botânico, na Luz, o rio Tietê, o alto de Sant'Ana. Examinou plantações de chá, de café, admirou a elegância das nossas araucárias (que chamou de "pinheiro especial do Chile") e observou nos caminhos dos arredores, em terreiros de casas rústicas, os esquisitos mastros com as bandeirolas caipiras de São João. Verificou também a existência dos famosos galos músicos, das temíveis vespas negras (que deviam ser as nossas mamangabas) e, como surpresa, uma serpente coral deslizando quase em baixo do seu quadrúpede.

$\mathrm{Na}$ cidade propriamente dita, averiguou o sistema de construção das casas, a disposição dos quarteirões, o grande número de igrejas e conventos, a Catedral em obras e os diferentes logradouros. "O palácio, ou casa do Governo, ocupa os dois lados de uma grande praça, e a Universidade, antigamente um convento, um lado de outra praça". Universidade, título pomposo e complexo, vinha a ser simplesmente a Academia de Direito, naquele mês de dezembro deserta por causa das férias. Mesmo assim, teve ARNOLD a curiosidade de visitá-la. Não se referiu às salas de aulas (talvez fechadas), nem à Biblioteca. Nada disse também sobre lentes ou estudantes. O que lhe chamou a atenção foi, num pequeno pátio, o túmulo de um professor alemão de 32 anos, "Julius Frank". (O nome vem entre aspas, como se indicasse outra identidade, ou mesmo algum significado oculto). Era "um singelo obelisco, sobre uma base quadrada, com uma simples inscrição; circunda-o uma grade de ferro com um papagaio ou coruja dourada em cada quina. É um bonito monumento (tudo, menos as corujas)". Concluiu afirmando que esse Frank era amigo do beberrão Hopkins, que se gabava de o haver tido como companheiro de libações. (Júlio Frank, professor do Curso Anexo, faleceu em São Paulo em 19 de junho de 1841).

O leitor desprevenido pergunta-se, de imediato, que crédito mereceriam tais palavras de um ébrio habitual, e como pôde um bacharel acolhê-las entre as suas observações. Um viajante torna-se simplório ao acreditar em tudo quanto ouve! HoPKINS ainda "empurrou" esta para o caderno de notas de ARNOLD: anos antes, em São Paulo, tinha visto passar sobre sua casa, como se fosse uma nuvem, um bando de vespas negras (sic), que demoraram três quartos de hora, ou 45 minutos, para su- 
mir no horizonte, ao Norte .. O fenômeno, verificável nas regiões sulinas do Brasil, correspondia à migração total de milhões de gafanhotos, que formavam, no seu deslocamento aéreo, nuvens escuras. As vespas, nas suas rápidas incursões agressivas, podiam quando muito produzir sombras fugazes.

Fique aí registrada, como curiosidade, a bacharelice do ianque. Não teve ocasião, na sua apressada passagem por São Paulo, de trocar idéias com algum professor ou acadêmico de direito. $\mathrm{O}$ caiporismo levou-o à intimidade de um homem rústico e borracho, como Hopkins, que o inundou de fanfarrices e pataratas ${ }^{1}$.

6 - Nos meses de junho e julho de 1855 percorreu a Província de São Paulo um missionário metodista norte-americano. Chamava-se JAMES COOLEY FleTcher. Reunindo, mais tarde, as observações feitas durante a sua viagem pelo Brasil com as outras, anteriormente publicadas pelo colega protestante DANIEL PARRISH KIDDER, editaram ambos, em Filadelfia, um novo trabalho, refundido e ilustrado, que se chamou O Brasil e os Brasileiros. A obra, em dois volumes, popularizou-se em sucessivas edições, tornando-se nos países de língua inglesa livro clássico de consulta para quantos se interessassem pelo longínqüo Império sulino governado por D. Pedro II.

O Reverendo FLETCHER, portanto, arribou certo dia a Santos, subiu a cavalo a Serra do Cubatão e, ao chegar a São Paulo, à noitinha, sentindo frio, "um frio que pedia sobretudo", já encontrou "vários estudantes de direito bem encapotados", e com eles travou conversação, achando-os "extremamente afáveis e comunicativos".

Hospedado no Hotel Charles, o único hotelzinho que então funcionava na Paulicéia, lembrou-se de um amigo no Rio de Janeiro e escreveu-lhe carta, desafogando as impressões recentes. Leiamos alguns trechos:

“26 de Junho de 1855.

"Estou num quarto frio - tão frio como nunca senti antes no Brasil. A lua está brilhando fria-

1. Samuel Greene Arnold, Viaje por América del Sur. 1847-1848. Prólogo de José Luis Busaniche. Prefácio de David James. Emece. Editores, S.A. Buenos Aires. (Sem data).

Frederico de Barros Brotero, A Vida do Dr. João Dabney de Avelar Brotero. Excursão aos Estados Unidos da América do Norte em 184\%. Discursos. Relatórios etc, São Paulo, 1945. (Edição do Autor) 
mente; os homens quasi tiritam de frio debaixo dos seus capotes (desejava ter um), e a única coisa que possui calor é a vela, que derrama sua luz baça sobre esta folha de papel. Devo, todavia, excetuar o ativo esforço de uma corneta distante, que realmente enche o ar da noite com a sua quente melodia."

"Senti um mais profundo respeito por São Paulo do que por qualquer outra cidade sul-americana que tenha visitado. E maior do que eu esperava, e suas casas, com suas goteiras pendentes, dão-lhe uma aparência não muito diferente das de Vevay, no Lago de Genebra. Essas goteiras avançam sobre as ruas, cinco ou seis pés, protegendo os transeuntes da chuva e do sol, e dão ao conjunto um pitoresco suíço."

"Meu sentimento de respeito, todavia, não se originava do tamanho da cidade, nem de seu pitoresco, mas de se notar um ar mais intelectual e menos comercial em seus habitantes do que eu vira em outra qualquer parte do Brasil. Não se ouvia a palavra dinheiro constantemente soando aos ouvidos, como no Rio de Janeiro. Há nada menos de quinhentos estudantes de direito na escola que aí funciona, cujo aspecto realmente evoca as escolas de direito dinamarquesas, da Universidade de Harvard e dos estudantes de Heildelberg. O gênero estudante é o mesmo no mundo, - cheio de travessura, graça e malícia. $\mathrm{Na}$ semana de minha chegada, algumas dezenas de estudantes tinham promovido uma algazarra no teatro (como um deles elegantemente a denominou), tanto assim que o Presidente da Província ordenou que forte contingente de polícia estivesse presente à próxima representação, e não foi sem dificuldade que manteve a ordem."

"Ao entrar na cidade, topei com um grupo desses jovens cultores do direito, que me conduziram ao hotel onde muitos de seus colegas estavam perdendo o tempo jogando bilhar; e, a julgar pelo som das bolas rolando e pelas belas tacadas em hora tão adiantada, era fácil imaginar que teriam pouca oportunidade para preparar as suas lições da manhã." 
Apostilando as reflexões exaradas em 1839 pelo pastor KIDDER, o diligente FLETCHER, em outro passo da obra, comentou:

"Em 1855, a prosperidade da Academia de Direito não se podia pôr mais em dúvida, pois nessa época havia duzentos e noventa e seis estudantes nas cinco classes e mais trezentos no curso preparatório. Lendo a lista das matérias desse curso, achei (salvo a língua grega) ser muito semelhante à da maior parte dos institutos congêneres nos Estados Unidos. Sob a direção do Dr. Brotero, a Faculdade paulista tornou-se extremamente popular, e, sem dúvida, muito mais prática do que nos primeiros anos de sua existência. É aqui e na Escola de Direito de Pernambuco (que contém trezentos e vinte estudantes no curso regular), que os estadistas do Brasil recebem o tipo de educação que tanto convém, muito mais para o Parlamento imperial e as várias assembléias legislativas de sua terra, do que os cursos que, para o mesmo fim, existem nos países hispano-americanos".

Após rápida excursão ao interior para conhecer de perto a vida nas fazendas, regressou FLETCHER à Capital. Ali, foi visitar o Dr. BRoTERo, ao qual, na sua linguagem nem sempre apropriada, apontou como "o Presidente da Academia de Direito, que tão justamente celebriza São Paulo. Encontrei na Sra. Brotero uma cidadã de Boston. Também travei relações com o Sr. Brotero Jr., para quem o Sr. Octaviano, o digno redator do "Correio Mercantil", do Rio, dera-me uma carta de apresentação. Esse cavalheiro, que passa por ser um dos homens de maior destaque de São Paulo, possui larga visão das coisas, e teve a vantagem de viajar pela Europa e pela América do Norte".

(Dois pequenos enganos cometeu FlETCHR: D. Ana (Nancy) Dabney, esposa do Dr. José MARIA DE Avelar Brotero, era filha de antigas famílias de Boston, ela porém nascida em Bordeaux, França, quando seu pai ali exercia funções consulares. Descendia de John Alden, um dos peregrinos do "Mayflower". O Sr. Brotero Jr. vinha a ser o Dr. JoÃo DABNEY DE AVELAR BROTERo, formado na turma de 1846, e já naquele mês de junho de 1855, com vinte e nove anos de idade, lecionando na Academia de Direito. Não viajou pela Europa, e sim no Arquipélago dos Açores e Estados Unidos da América do Norte.) 
Tendo de retornar a Santos, para prosseguir na sua jornada, o Reverendo J. C. FLETCHER gozou ainda da companhia de vários rapazes, que designou como "meus amigos estudantes", e que para lá seguiam a cavalo. A narrativa do missionário protestante evidencia à larga a presença dos acadêmicos de direito na rotina da época: ao chegar, estudantes; na Capital, estudantes e professores; ao retirar-se, ainda e sempre estudantes!

Pena que no livro de KIDDER e FleTcher, cuja primeira edição saiu em 1857, não apareça, entre as gravuras, nenhuma vista do Largo de São Francisco com o vetusto edifício da Academia ao fundo.

7 - Na última semana de setembro de 1858 chegou a São Paulo o dr. Roberto Avé-Lallemant. Era alemão, médico de renome e havia clinicado longos anos no Rio de Janeiro. Espírito inquieto, gostava de viajar e naquele ano já havia percorrido todo o Sul do Brasil - litoral, lagoas, rios, serras e campos - utilizando todos os meios possíveis de condução, e na maioria das vezes, sozinho! Possuía largos conhecimentos científicos e literários e servia-se com facilidade do idioma português, o que certamente favoreceu bastante os seus contatos com o povo. Daí as observações realistas e minudentes, que constam no livro que escreveu - Viagem pelo Sul do Brasil, publicado em Leipzig em 1859.

Pouco mais de uma semana permaneceu na Paulicéia. Tempo suficiente para se inteirar das condições de vida dos numerosos patrícios alemães que ali residiam e para conhecer as curiosidades locais. De São Paulo e dos paulistanos tinham-lhe contado "magnificências", que no entanto pouca excitação lhe despertaram.

Ao descrever os edifícios públicos, observou numa curiosa associação de idéias: "As igrejas que vi são bonitas, algumas ornadas, no entanto nenhuma me causou grande impressão. A Faculdade de Direito dá uma boa impressão e parece-me o mais notável de todos os edifícios da cidade".

A inclusão, num só parágrafo, de igreja e Academia explica-se pela contigüidade do templo consagrado a São Francisco e pelo conhecimento, que o Autor tinha, de haver sido outrora um convento o prédio onde funcionava o Curso Jurídico.

Algo puritano, levando muito a sério os fatos, escandalizou-se AvÉ-LALLEMANT com o que viu no bonito e agradável Jardim Botânico no bairro da Luz: uma estátua de Vênus profanada "com graçolas de mau gosto" Feitas por quem? 
Verberou o alemão: "deve ser considerado como um regresso à tatuagem e à grosseria dos índios que a mocidade acadêmica de São Paulo tenha coberto de más inscrições uma Vênus saindo do banho, cópia de um célebre motivo, quebrando com chalaças a lápis o encanto do arredondado mármore."

Mas em que se baseou o ilustre facultativo para atribuir aquele milagre anatômico aos santos estudantes? Caixeiros, soldados ou gaiatos avulsos podiam também ser indigitados como autores da façanha. . Verdade é que AvÉ-LaLlEMANT freqüentara Universidades européias (Berlim, Paris, Kiel) e devia conhecer, por experiência, aquilo que poderíamos chamar de atividades culturais paralelas da classe estudantil.

Soube, por isso mesmo, avaliar o que significava a existência da Academia, com 500 ou 600 alunos, segundo os seus cálculos, numa cidade como São Paulo, escrevendo: "A Faculdade de Direito pede um estudo muito mais amplo do que posso dar aqui, pois o instituto é da máxima importância para todo o país. Reservo uma descrição exata para outro tempo."

Ignoramos se AvÉ-LALLEMANT chegou a esboçar ou publicar esse estudo.

8 - Personalidade altamente qualificada, o barão suíço JoÃo JACOB VoN Tschudr não visitou a Província de São Paulo, no ano de 1860, como um simples viajante à cata de sensações e novidades. Naturalista famoso, aqui veio credenciado como Ministro Plenipotenciário da Confederação Helvética no Brasil, a fim de pesquisar "in loco" a situação dos imigrantes suíços radicados na lavoura paulista, bem como o sistema das "colônias de parceria", situação e sistema objeto de dúvidas e protestos no Velho Continente.

Autêntico europeu, com formação cultural sedimentada em Universidades, não perdeu VoN Tschudi o vezo d'além oceano. Logo nos primeiros dias de permanência na Capital, precisou de um ferrador para a sua mula doente e foi procurá-lo (como escreveu) "na praça da Universidade", expressão que um paulistano traduziria: no Largo de São Francisco, onde fica a Faculdade de Direito. .

Pouco depois, ao falar da Academia, insistiu na designação: "O arco do pórtico da igreja de São Francisco e do atual edifício da UNIVERSIDADE (grifo nosso) é trabalhado em belo mármore italiano, mas que dificilmente se descobre, devido à grossa camada de tinta, de um amarelo sujo, com que foi recoberto". 
Dando primazia aos objetivos de sua viagem, VoN TSCHUDI deslocou-se a cavalo para o Interior, percorrendo as regiões de Jundiaí, Campinas, Amparo, Limeira, Rio Claro, Piracicaba, Capivari e Itu. Entre as fazendas que inspecionou, algumas pertenciam a bacharéis em Direito por São Paulo, como as do ituano JosÉ ElLAS PACHECO JoRDÃo, da turma de 1841. Em Campinas, para tratar da "sorte dos orfãos dos colonos, assunto este então inteiramente descurado", recorreu aos préstimos do juiz municipal dr. Tito Augusto Pereira DE MAtos, reconhecendo nele "um jurisconsulto de grande valor, e um cavalheiro muito leal e sincero". Com efeito, aquele magistrado, baiano de nascimento, depois de se formar em São Paulo em 1857, defendera teses com pleno êxito, fazendo jus, portanto, ao título de "doutor".

Em agosto de 1860 o Barão VoN Tschudi estava de volta a São Paulo. "No dia seguinte à minha chegada (rememorou ele), fui procurado por uma deputação de estudantes, que me convidou a visitar sua ALMA MATER, frisando que o convite não visava o ministro, porém o homem de ciência".

Aceitou. A primeira visão que reteve ao entrar na Academia foi um pequeno pátio, onde sob um obelisco jaziam os restos mortais de um alemão, falecido em 1841, "que foi professor de história nessa universidade (sic), sob o pseudônimo de Julius Frank". Pseudônimo, dizem os dicionários, é um nome falso ou suposto. Não deixa de ser curioso que um europeu de passagem pela cidade soubesse desse fato tão ciosamente guardado em sigilo pelos interessados, a saber - que Frank não era Frank... Afirmou também VoN TschUdi que o compêndio de história universal de JúLIo FRANK ainda era adotado nos cursos preparatórios e que na sala onde dera aulas "existe seu retrato toscamente pintado".

Esquadrinhando a escola, observou: "As salas de aulas são sombrias e pouco confortáveis; somente a grande biblioteca é arejada e inundada de luz". Teria a biblioteca cerca de nove mil volumes, entre eles alguns de valor. Não encontrou ali livros alemães; franceses, porém, havia vários, representativos da literatura da época. "Dos onze professores de ciências jurídicas, lentes da Faculdade, e dos seis suplentes, apenas dois terços se encontram sempre em São Paulo; os restantes ocupam cargos públicos fora da cidade ( .) É fácil de se compreender que a Faculdade fique prejudicada visto que seus melhores elementos dela vivem afastados."

Outras considerações de VoN TsCHUDI: "Entre os estudantes, cujo número chega a 500 mais ou menos, reina animada 
atividade, e o campo predileto são as belas letras e a publicação de artigos políticos. Seria melhor que, em lugar da política, que tão cedo preocupa os jovens cérebros, com suas discussões, fosse dedicada atenção aos livros didáticos. Os estudantes fundaram várias sociedades científicas, algumas das quais publicam revistas dignas de nota, por exemplo, a Sociedade Ensaio Filosófico Paulistano, com a Revista Mensal, o Ensaio Acadêmico com os Anais, a Imprensa Acadêmica, etc. Algumas destas publicações tiveram vida breve devido ao desinteresse do público e a dificuldades financeiras.

"Desde alguns anos esboçou-se um movimento para transferir a Faculdade de São Paulo para o Rio de Janeiro. Não considero tal projeto feliz (...) O clima bom e moderado da cidade provinciana presta-se mais à atividade mental do que - esgotante calor da Capital. É mais fácil congregar os estudantes em São Paulo, em união cada vez mais estreita, do que no Rio de Janeiro, com suas múltiplas ramificações. A vida mais econômica de São Paulo é, por fim, um fator preponderante para o grande número de estudantes menos favorecidos, em favor de São Paulo.

"Falei com estudantes que haviam frequentado durante alguns anos as aulas da Faculdade de Pernambuco e tinham vindo após matricular-se na de São Paulo. Disseram-me esses rapazes que naquela faculdade havia maior número de professores e alunos, mas que nesta o estudante aplicado tirava maior proveito dos seus estudos, devido ao clima favorável e à maior concentração. A vida intelectual de São Paulo é mais livre e a orientação científica mais moderna que em Pernambuco, onde predomina ainda o romanismo".

Todas essas opiniões de J. J. VoN Tschudi foram incluídas na obra, em cinco tomos, que em 1866 publicou em Leipzig, sob o título Reisen durch Süd-Amerika. Dessa obra, foram traduzidos em português os capítulos consagrados às regiões do Rio de Janeiro e de São Paulo.

9 - Em agosto-setembro de 1862 um francesinho sentimental, chamado FRÉDÉRIC HoUSSAY, permaneceu vários dias na Paulicéia, entregue aos devaneios e extasiado com a beleza das paisagens. A sua caminhada predileta se dirigia sempre para os lados do jardim aberto no bairro da Luz, onde solitário à sombra de um caramanchão passava momentos calmos, aprendendo a língua portuguesa e apreciando plantas exóticas, pássaros e borboletas. 
Em cartas para os parentes na França (reunidas anos mais tarde no livro De Rio de Janeiro a S. Paulo, editado em Paris, 1877), contou que em São Paulo se hospedava num hotel ocupado por negociantes estrangeiros, "qui parlent toutes les langues, la mienne exceptée". Achou as ruas da cidade largas, com lojas repletas de artigos de luxo. As casas ostentavam balcões à moda de Espanha, com um toque de originalidade. Alguns edifícios imponentes atraiam a atenção dos transeuntes. Teatros havia dois: um ameaçando cair, e um outro - que não acabava nunca de ser feito (era o São José, inaugurado em 1864). A Capital, segundo ele, teria uns 46.000 habitantes. No Pátio do Colégio, os muros brancos da velha construção erguida pelos jesuítas na colina contrastavam com o verde das várzeas ali perto e com o azulado das montanhas que delimitavam o horizonte, ao longe.

Escreveu ainda o autor que a cidade, "grâce à ses souvenirs historiques et au caractére entreprenant des Paulistes, acquiert chaque jour une nouvelle importance. São Paulo a une école de droit d'ou sont sortis des hommes éminents. Elle a en outre une belle bibliotéque, fondée par le viconte de Congonhas (...)". Nenhuma informação nos deu HousSAY de haver convivido com moços estudantes.

Enquanto o francesinho idealista admirava a terra que não era a sua, as crônicas da cidade, exatamente nesses dias de agosto-setembro de 1862, deixavam transparecer uma outra faceta da vida acadêmica, a revelar através do jornal Correio Paulistano, que nem tudo eram flores, poesia e bucolismo no pacato burgo daqueles tempos.

Alguns exemplos, ao acaso. O poeta calouro LUIS NicoLAU FAGUNDES VARELA, ainda na metade do ano, já havia sido reprovado - por faltas! Na Rua da Glória, às onze da noite, o quintanista MANoEl Eufrásio Correa foi vítima de uma emboscada e saiu ferido com uma facada no peito. Na Rua das Flores, gaiatos se divertiam dando vaias em quem passava, daí resultando um conflito em que um acadêmico ficou maltratado. O estudante de direito ANTONio CORREA DE OLIVEIRA, gaúcho, requereu à delegacia de polícia um "termo de segurança" contra dois colegas de turma, os campineiros JoÃo QUIRINo Do Nascimento e Manoel Ferraz de Campos Salles. E por questões de segurança, o delegado mandou reforçar as patrulhas nas freguesias da Sé e de Santa Ifigênia...

10 - Se houve viajantes que, na sua passagem por São Paulo, se preocuparam em conhecer a Faculdade de Direito do Largo de São Francisco, para depois, em breves linhas ou pági- 
nas longas, dar a respeito uma notícia ou opinião criteriosa, outros surgiram, quais embusteiros, a anunciar coisas que nunca viram, confundindo os leitores com informações errôneas.

Um deles foi o Comte DE LA HuRE, que na obra L'Empire du Brésil (Paris, 1862), p. 553, comunicou aos contemporâneos e aos pósteros que em São Paulo havia "une école de droit et une université".

O pior é que logo depois apareceu outro trapalhão para repetir a fábula, copiada provavelmente do anterior. Também francês, por coincidência, ADoLPHE D'ASSIER assinalou no livro Le Brésil Contemporain (Paris, 1867), p. 239, que em São Paulo "une Université et une école de Droit en font aujourd-hui un centre intellectuel de premier ordre".

A novidade, se verdadeira, poderia quem sabe afagar a vaidade pessoal do Imperador D. Pedro II, sempre zelando pela instrução e cultura dos súditos brasileiros; mas incomodaria sobremaneira o Ministro da Fazenda, a rever contas, cálculos e verbas...

11 - Entre os meses de janeiro e setembro de 1866, o anglo-saxão JoHN CODMAN, tratando de seus interesses, navegou diversas vezes do Rio de Janeiro para Santos. Nessas viagens de ida e volta, conforme relatou mais tarde, gozou freqüentemente da companhia de professores e estudantes de direito de São Paulo. Os rapazes pertenciam à elite das famílias brasileiras e a bordo constituíam sempre grupos joviais e galhofeiros. Codman julgou-os bons camaradas, distintos, de boas maneiras, muitos deles versados em autores clássicos e matemáticas. Os estudantes leigos, todavia, demonstravam desinteresse e pouco preparo em assuntos de religião.

Estando em Santos, certo dia, por conveniências pessoais, resolveu Codman ir a São Paulo pelo trem de ferro, galgando a serra pela via recém-aberta ao tráfego. Achou perigosa a nova estrada, e tremeu ao ver os abismos ao lado e embaixo dos trilhos... Mas os encantos da paisagem e o ar puro das matas compensaram até o desconforto dos vagões.

Em São Paulo hospedou-se no Hotel da Europa. Do que viu e observou na Capital ficou um registro no livro Ten Months in Brazil with Notes on the Paraguayan War (Edinburgh, 1870).

Depois de se referir à cidade como entreposto comercial, enfatizou que as principais instituições culturais do Império se achavam bem situadas em São Paulo, que desfrutava do melhor clima do Brasil, sendo certo que o ar puro contribuía para a 
formação de mentalidades arejadas. Identificou na Paulicéia, considerando-os em perfeitas condições, três cursos: "education in Law" (Faculdade de Direito), physic (?), e "divinity" (Seminário Episcopal).

Mas era tempo de férias quando transitou por ali, e a calma reinante na cidade testemunhava quanta falta faziam os estudantes, que formavam sem dúvida a parte mais animada e vivaz da população. Muitos daqueles rapazes pertenciam a ricas famílias do Império e contribuíam com dinheiro graúdo para a movimentação do comércio local.

Por causa mesmo das férias, teve JoHn Codman de se satisfazer com uma visão exterior "of the college buildings" Não pôde, portanto, conhecer a Faculdade de Direito por dentro, com o claustro do antigo convento franciscano, as salas de aulas e a biblioteca.

12 - De origem alemã, OSCAR CANSTATT trabalhou como agrimensor em diferentes pontos do Brasil. Por força de sua profissão, andou jornadeando por várias províncias do Império. Inteligente, observador, escreveu um livro publicado em Berlim, 1877. Vale notar que naquela época o Brasil oferecia amplas possibilidades à imigração européia. Assim, qualquer obra versando o gigante inexplorado da América do Sul provocava no velho continente atenção e curiosidade, sobretudo entre os que sonhavam recomeçar a vida num país novo. Muitos anos depois, o trabalho de CANSTATT foi traduzido para a língua portuguesa, sob o título Brasil - A Terra e a Gente (1871).

Por volta de 1870, Oscar CANstatt visitou São Paulo. Ao contrário de todos os outros viajantes, que pela via marítima desembarcavam em Santos, e depois subiam a serra, cavalgou ele pelo sertão, de Minas Gerais, onde estivera, até a cidade paulista de Jundiaí. Ali tomou um trem, que o conduziu à Estação da Luz, na Capital do café.

Pouco tempo ficou em São Paulo. Mas encontrou ocasião para registrar: "A Universidade que São Paulo possui está instalada num antigo convento franciscano. Faltou-me tempo para vê-la por dentro." (Como bom europeu, não teve dúvidas o autor em designar a Faculdade de Direito como Universidade). E concluiu: "Os paulistas orgulham-se muito dos seus institutos científicos e demais instituições públicas e crêem que nisso não ficaram atrás mesmo de cidades europeias. Até que ponto isso tem fundamento, não tive tempo de averiguar no pouco que me demorei lá. Os arredores da cidade são maravilhosos $(\ldots) "$. 
13 - Christopher Columbus ANDREws, cidadão norte-americano, foi consul-geral de sua nação no Brasil. Homem culto, interessava-se pelos assuntos de instrução pública. Em maio de 1884, estando no Rio de Janeiro, resolveu conhecer a grande e rica Província de São Paulo. Tomou um navio, desembarcou em Santos e subiu a Serra do Mar num trem da "São Paulo Railway". Ei-lo, então, na serena e civilizada Paulicéia, a percorrer os bairros e jardins e a visitar as instituições públicas.

Poucos anos depois, no livro Brazil, Its Condition and Prospects (New York, 1887), relatou as suas impressões da Capital paulista. Não se esqueceu da Faculdade de Direito, sobre a qual disse: "Among the prominent things in São Paulo is the National Law School". Visitou-a num dia de feriado acadêmico. Informou aos leitores de língua inglesa que funcionava "in an old Jesuit church and monastery", notícia que certamente não agradaria nem aos padres franciscanos, nem aos ciosos acadêmicos de direito. .

Admirou-se ANDREws da grossura das paredes de barro do velho convento, pintado de branco por fora. No interior, anotou a existência de vários retratos de corpo inteiro de professores da escola: "Besides the room for the library, there are two fine large rooms or halls, with several full-lenght portraits of professors (...)". Chamou-lhe também a atenção, em outra sala, talvez a da congregação, um quadro especial: "in an inner room was a good full-lenght portrait of the Emperor, Dom Pedro II".

Ao entrar na biblioteca, verificou que estava em reformas. Grande parte dos livros se esparramavam pelo soalho atapetado. Correndo os olhos por eles, comprovou que eram velhos e traindo a influência da cultura francesa: "They had a French look outside, and the most were apparently a century or so old." Ao procurar obras em língua inglesa, só encontrou, de origem britânica, Burn's Justice and Chitty's Commercial Law. Não viu nenhum livro de direito norte-americano, "except three copies, in two volumes each, of Wheaton's International Law, in french". Da famosa Edinburgh Review descobriu uma coleção, à qual pareciam faltar os números mais recentes.

Não esquecer que em maio de 1884, por ocasião da visita de Mr. ANDREWs, a Faculdade de Direito sofria os retoques da reforma iniciada no ano anterior pelo diretor Dr. ANDRÉ AUGUSTO DE PÁDUA FLeURY. 
14 - Pouco tempo antes da nossa proclamação da República, o intelectual francês ALFRED MARC, membro da Sociedade de Geografia Comercial de Paris, veio conhecer de perto as terras de Santa Cruz desbravadas pelo rijo povo português. Anotou e coligiu, de Norte a Sul, uma grande quantidade de informações. Ao regressar à civilizada Europa, publicou em dois volumes o livro Le Brésil - Excursion a Travers ses 20 Provinces. (Paris, 1890).

Para visitar São Paulo, poderia vir do Rio de Janeiro, da Corte, pela ferrovia, gastando nesse percurso doze horas. Preferiu, pelo pinturesco e emoções da viagem costeira, a via marítima. Desembarcou em Santos e subiu a serra no trem da "Inglesa", ou por outra, da "São Paulo Railway". Ei-lo, enfim na bela Capital paulista, que avaliou ter perto de 65.000 habitantes, exibindo ainda muitos prédios velhos com a típica feição colonial lusitana, em contraste com bairros novos e arejados, onde se descortinavam ruas bem traçadas e construções modernas, de requinte e bom gosto. A província prosperava, graças aos negócios do café, por isso não estranhou certo luxo evidente em vários edifícios públicos. A vetusta Academia de Direito, reformada em 1883-1884 pelo diretor dr. PÁDUA FLEURY, também mereceu dele uma visita, como registrou:

"S. Paulo possède l'une des deux Facultés de Droit de l'Empire, sans parler de ses 80 écoles publiques primaires, de son cours secondaire, de son séminaire épiscopal superbement amenagé pour 400 élèves, de son lycée des arts et métiers, de son école normaie, etc. C'est un titre fort estimé que celui de BACHAREL EM DIREITo formé à S. Paulo. Sans vouloir entrer ici dans aucune discussion à ce sujet, il faut bien constater que les Brésiliens vantent la profondeur des études juridiques qu'on fait à cette Faculté, et qu'ils les estiment bien supérieures à l'enseignement qui est distribué par nos Facultés similaires de France. Je crois que cet orgueil est justifié".

15 - Em 1909 foi publicado em Paris o livro Le Brésil au $X X e$. Siécle, da autoria de PIERRE DENIS. O novo século apenas amanhecia, mas a França revelava-se ainda pujante, expandindo pelas demais nações opulências de arte e cultura e os tentáculos dos seus numerosos interesses comerciais.

O Brasil desde os tempos do Império vinha recebendo da França benéficas influências de civilização. São Paulo, terra de ricos fazendeiros e proprietários, primou nesse sentido. Costumavam os paulistas abonados ir à França passar férias, tratar da saúde em estações de água, ou fazer compras nos 
luxuosos magazines, antiquários e livreiros parisienses. De lá voltavam enriquecidos de cultura e refinamento social, falando com desenvoltura a língua de Molière, Balzac e Victor HUgo.

Os gauleses, por sua vez, tinham os olhos voltados para o Brasil. Uns, com fitos de lucro. Outros, curiosos em relação àquele país novo, pleno de possibilidades, com terras ainda a desbravar e enigmas científicos a pesquisar.

Pierre Denis interessou-se muito por São Paulo, que considerou o verdadeiro centro econômico da nação. Fez justiça aos paulistas das velhas famílias, que com a sua têmpera e iniciativa de autênticos bandeirantes haviam contribuído decisivamente para o progresso do Estado, formando fazendas e mais fazendas em regiões pioneiras e abrindo caminhos de ferro para a circulação das riquezas. A colonização em grande escala era recente e os imigrantes europeus, graças ao ambiente social aberto, sem preconceitos, tendiam a ser absorvidos com facilidade pela massa geral da população.

A Capital paulista já se mostrava uma grande e movimentada cidade, não apenas por causa dos negócios. A cultura também merecia atenções cuidadosas. Por isso considerou PIERRE DENIS que "Saint-Paul est à la tête du Brésil par la valeur de ses écoles, et par le souci apporté à l'organisation de l'enseignement public".

Nesse variado contexto social, econômico e intelectual, salientava-se por suas fecundas tradições, e pelo seu prestígio sempre atuante, o vetusto casarão do Largo de São Francisco, como reconheceu o autor francês nestas breves linhas: "La Faculté de Droit de Saint-Paul a exercé une grande influence sur le Brésil entier par les générations de juristes et d' hommes d' état qu' elle a formeés".

16 - No primeiro decênio deste século, um inglês de nome original, CHARLES WILLIAM DOMVILLE-FIFE, perlustrou o Brasil de Norte a Sul, assombrado com as virtualidades "of this monster nation in the making". Como um simples "chronicler", observou, estudou, recolheu fotografias. A sua curiosidade de viajante ficou perpetuada num livro ilustrado, The United States of Brazil, saído dos prelos em Londres, 1910.

Um dos capítulos da obra versa a Capital de São Paulo, aprazível, bem pavimentada e iluminada, limpa, com serviços de "tramways" para todos os bairros. A cidade lembrava outras da Europa. Numerosas livrarias, museus (como o do Ipiranga), escolas, bibliotecas, periódicos atestavam a cultura, o desenvolvimento intelectual do povo, bem como o zelo dos governantes. 
Os jornais, adiantados, à altura do progresso; mas o britânico verificou neles isto: "the phraseology extremely grandiloquent..." (Se ele fosse pesquisar, descobriria que muitos dos redatores eram estudantes ou bacharéis em Direito...).

Um fato chamou a atenção de DomvILLE-FIFE, ao considerar os estabelecimentos públicos. Muitos edifícios de fins educacionais, pela vastidão e imponência, se destacavam na cidade, semelhando palácios: "The Public, the Polytechnic, the Normal, and many others, are buildings of such magnificence that they could easily be mistaken for the Governor's Palace".

Entre esses "many others" podia o Autor incluir, com vantagem, o altanado, porém discreto, prédio da Faculdade de Direito, apresentando enorme testada no Largo de São Francisco. Mas o inglês parece não ter tido maior interesse na velha Academia, dela não publicando sequer uma fotografia no seu livro.

\section{Os que Ficaram Nobres. Relação dos Bacharéis por São Paulo que Mereceram Títulos Nobiliárquicos.}

Relacionamos aqui os bacharéis formados pela Faculdade de Direito de São Paulo que mereceram títulos de nobreza.

Declara-se, antes, o ano em que cada um deles se diplomou, em seguida o título, por fim o nome completo. Mencionam-se, também, circunstâncias especiais ou interessantes.

Como qualquer outro catálogo, não ficará este isento de omissões ou enganos. Apontem-nas, por favor, os que melhor conhecerem o assunto.

Turma de 1831 - Marquês De Muritiba - Manoel Vieira Tosta. Era baiano. Foi um dos grandes do Império. Transferido da Universidade de Coimbra, fez parte do pequeno grupo de seis estudantes, que primeiro colaram grau no Curso Jurídico de São Paulo, inaugurando no Brasil o ciclo do bacharelismo. Tornou-se Barão com grandeza em 1855, Visconde com grandeza em 1872 e Marquês em 1888. Faleceu quase nonagenário, no Rio de Janeiro, já em tempos da República.

1831 - Visconde De URUguaI - PaUlino José SoARES DE SouzA. Nasceu em Paris, quando o pai lá estudava medicina. Cursou quatro anos de Direito em Coimbra. Foi um dos primeiros bacharéis em direito no Brasil. Notável jurisconsulto, político, diplomata, homem de letras, o seu nome honrou a Academia paulistana onde recebeu o seu diploma. Visconde com grandeza em 1854. 
1832 - MARqUÊS DE SÃo VICENTE - JosÉ ANTÔNIO Pimenta Bueno. Nasceu na cidade de Santos. Ingressando em 1828 nas Arcadas franciscanas, integrou a primeira turma acadêmica, "filha legítima da nossa velha Academia", como disse o dr. AlmeIDA NogueIRA. (A turma de 1828-1832, matriculada logo após a inauguração da escola, foi a primeira a estudar na Paulicéia, por completo, os cinco anos do curso). De origem obscura, paupérrimo, PIMENTA BUENo ascendeu por seu valor pessoal às mais altas posições do Império. Os seus feitos e trabalhos estão inscritos nas páginas de nossa História. Ministro do Supremo Tribunal de Justiça. São de sua lavra diferentes obras jurídicas, sempre lidas e citadas, consideradas clássicas pelos subsídios que forneceram para o desenvolvimento do nosso Direito. Foi Visconde com grandeza em 1867 e Marquês em 1872.

Sem data - BARÃo DE Sousa QueIroz - Francisco AnTônio DE Sousa QUEIRoz. Fez o $1^{\circ}$ ano de Direito em Coimbra. Segundo Almeida Nogueira, estudou em São Paulo, anos de 1829 e 1830 , apenas o $2 .^{\circ}$ e o $3 .^{\circ}$ anos. (Deveria formar-se com a turma de 1832, mas não o fez). Foi na Província paulista proprietário rural dos mais abastados e esclarecidos. Baräo com grandeza em 1874. Dos seus doze filhos, quatro colaram grau na Academia de São Paulo: o primogênito, do mesmo nome do pai, em 1857; Nicolau (casado com uma filha do lente Conselheiro Brotero), em 1862; Augusto, em 1872; e José, em 1878.

1832 - Barão De QUARAIM - Pedro Rodrigues FernaNDES Chaves. Era gaúcho. Cursou dois anos em Coimbra, concluindo em São Paulo os seus estudos. Magistrado. Político. Barão com grandeza em 1855.

1833 - Visconde de ARaXÁ - Domiciano Leite RiBeIRo. Era de São João Del Rei, Minas Gerais. Foi um dos grandes do Império. Presidiu a Província de São Paulo em 1848. O seu nome passou à posteridade como cultor das letras. No seu curioso livro Reminiscências e Fantasias numerosas páginas são dedicadas a evocar a antiga Paulicéia e o ambiente acadêmico. Visconde com grandeza em 1872.

1833 - Barão de São JoÃo Nepomuceno - Pedro DE Alcântara Cerqueira Leite. Mineiro. Magistrado. Político. Barão em 1881.

1834 - Barão de São Diogo - Diogo TeiXeira de MACEDo. Magistrado. Político. Diplomata. Barão em 1873. 
1834 - Visconde de Niteró - Francisco de Paula DE Negreiros Saiño Lobato. Natural do Rio de Janeiro. Figura das mais destacadas no cenário político do Segundo Império. Visconde com grandeza em 1872.

1834 - $10^{\circ}$ Barão de Javari - JoÃo Alves Loureiro. Diplomata. Musicista. Nasceu na Corte e faleceu em Roma. Barão em 1872.

1834 - Barão de RAMALHo - JoAQUim IgNÁcio RAMALHo. Paulista, da Capital. Defendeu teses e recebeu o grau de Doutor em Direito em 1835. Lente catedrático da velha Academia onde estudou, foi também seu diretor desde 1891 até quando faleceu, em 1902, contando 93 anos de idade. Figura austera e benquista, publicou trabalhos jurídicos (como a Praxe Brasileira) que o consagraram como verdadeiro Mestre. Barão em 1887.

1834 - VisCONDE DE JAGUARI - JosÉ ILDEFONSO DE Sousa RAMos. Mineiro. Prestou assinalados serviços à causa pública. Mereceu em 1867 o título de Barão das Três Barras e, em 1872, o de $2 .^{\circ}$ Visconde com grandeza de Jaguari.

1835 - BarÃo dE LoRena - Estevão Ribeiro dE REzENDE. Era filho do Marquês de Valença. Barão em 1853. Barão com grandeza em 1867.

1835 - Barão do Desterro - JoÃo José dE Almeida Couto. Era baiano. Magistrado. Ministro do Supremo Tribunal. Barão em 1886.

1836 - Visconde dE SABARÁ - JoÃo Evangelista DE Negreiros Salão Lobato. Nasceu na Vila do Príncipe, Minas Gerais. Político, magistrado. Ministro e Presidente do Supremo Tribunal de Justiça. Irmão do Visconde de Niterói. Tornou-se Visconde com grandeza em 1888.

1838 - BarÃo de Vila Franca - Ignácio Francisco Silveira DA Mota. Era de Goiás. Magistrado. Político. Fazendeiro. Ligado pelo casamento à família dos Viscondes de Araruama. Barão em 1875. Barão com grandeza em 1877.

1838 - Visconde DE BOM ReTIRo - Luiz PedReira do Couto Ferraz. Nascido no Rio de Janeiro. Defendeu teses em 1839, tornando-se Doutor em Direito. Foi lente substituto e catedrático da Academia de São Paulo. Jubilou-se em 1868. Deputado geral e provincial. Presidente de diferentes províncias, Senador, Ministro do Império, sócio fundador do Instituto Histórico e Geográfico Brasileiro, teve vida pública das mais brilhantes. Amigo particular de D. Pedro II, acompanhou o 
Imperador em diversas viagens pelo Brasil e pelo exterior. Barão em 1867. Visconde com grandeza em 1872.

1839 - Barão do Penedo - Francisco Ignácio de CarVALHo Moreira. Alagoano. Estudou quatro anos no Curso Jurídico de Olinda e fez o $5^{\circ}$ ano em São Paulo. Foi no Segundo Império um dos vultos mais destacados da diplomacia brasileira, com atuação em Washington, Londres e Roma. Barão em 1864.

1841 - Visconde de ARInos - Tomás Fortunato DE BRITo. Fluminense. Diplomata de carreira. Ministro do Brasil em países da Europa e da América. Barão em 1872 e Visconde com grandeza em 1889.

1841 - BARÃo DE SERTóRIo - JoÃo SERTóRIo. Nasceu em Santos, filho de um negociante italiano. Foi magistrado e político. Barão com grandeza em 1888.

1845 - BARÃ̃o DE MAMORÉ - AMBRÓSIO LEITÃo DA CunHA. Natural do Pará. Estudou humanidades em Lisboa e cursou Direito em Olinda. Em São Paulo parece ter feito somente $05 .^{\circ}$ ano jurídico. Teve vida pública das mais ativas. Barão com grandeza em 1883.

1848 - BarÃo de AgUiAR DE ANDrade - Francisco Xavier da Costa AgUiar DE ANDRAde. Santista. Magistrado e Diplomata. Barão em 1876.

1848 - Visconde dE OURÉm - José CARLOS DE Almeida ARÊAS. Nasceu na Corte. Foi Ministro Plenipotenciário em Londres. Faleceu na França e lá foi sepultado. Barão em 1872 e Visconde em 1889.

1848 - Barão de Paranapiacaba - JoÃo Cardoso DE Menezes e Sousa. Era santista. Deu à causa pública valiosa colaboração. Mais conhecido como poeta e homem de letras. Barão em 1883.

1849 Visconde do DesterRo - José JoAquim FerReira VALE. Maranhense. Estudou os três primeiros anos de Direito em Olinda. Deputado e cônsul. O título foi-lhe concedido em Portugal em 1871.

1850 - Barão de Guimarães - José Agostinho Moreira Guimarães. Fluminense. Deputado e Presidente da Província do Espírito Santo. Alto funcionário do Ministério da Agricultura, Comércio e Obras Públicas. Barão em 1881.

1848-1851 - MARQUÊS DE ITU - ANTôNIo DE AgUIAR Barros. Paulista, ituano, filho do $10^{\circ}$ Barão de Itu. Estudou 
quatro anos em São Paulo e formou-se em 1852, em Olinda. Bacharel riquíssimo, foi também de enorme generosidade. Visconde em 1880, Conde em 1885 e Marquês em 1887.

1853 - Visconde de CRUZeiro - JeRônimo José TeIXEIRA JÚNIOR. Nasceu na Corte. Foi Deputado provincial, Senador, Ministro do Império, Diretor do Banco do Brasil. Faleceu em Roma. Visconde com grandeza em 1888.

1853 - Barão DE AlEnCAR - LeONEL Martiniano DE Alencar. Nasceu no Rio de Janeiro. Irmão de José de Alencar. Diplomata. Foi Ministro Plenipotenciário em países da Europa e da América. Barão em 1885.

1854 - CONDE DA PARNAÍbA - ANTôNIO DE QUEIroZ Telles JÚnior. Paulista, filho do Barão de Jundiaí. Foi o organizador e presidente da estrada de ferro Companhia Mogiana. Presidente da Província de São Paulo. Barão em 1880, Visconde com grandeza em 1887, e Conde por decreto de 3 de dezembro de 1887.

1854 - Barão de TATUí - Francisco Xavier Pais DE Barros. Paulista, de Sorocaba. Político. Fazendeiro. Casado em segundas núpcias com a viúva Baronesa de Itapetininga. Barão em 1879.

1855 - Barão de Itaipú - Francisco Manoel das ChaGAS. Paulistano, Barão em 1889.

1855 - Visconde?... Não! - GabriEL DE PaUla AlmeiDA MAGalhães. Este mineiro de São João Del Rei, rico, prestigioso, cheio de serviços à coletividade, "recusou In Limine o título de Visconde com que fora agraciado pelo ministério João Alfredo, em cujo grêmio contava quatro colegas e amigos". (Veja Silva Leme, Genealogia Paulistana, v. VI, p. 275-276).

1856 - CONDE DE DiNiz CoRdeIRo - LOPo Diniz CoRdeiRo. Fluminense. Cunhado do Barão de Werneck. O título de Conde foi-lhe outorgado pela Santa Sé.

1856 - BarÃo de ANDRAde Pinto - EduARdo DE ANDRADE PINTo. Fluminense. Moço fidalgo. Foi deputado e Ministro do Império. Barão em Portugal.

1857 - Barão de Sousa Lima - José Antônio de SoUSA LiMA. Mineiro. Presidente das Províncias de Pernambuco e do Rio Grande do Sul. Fazendeiro em terras fluminenses. Barão em 1883.

1858 - Visconde de OURo PReto - Afonso Celso DE Assis Figueiredo. Um dos maiores varões de nossa História. 
No dizer de Almeida Nogueira, o político "que se constituiu, depois do Imperador, o primeiro cidadão do Brasil monárquico". Visconde com grandeza por decreto de 13 de junho de 1888.

1858 - Barão De Homem DE MELO - Francisco IgNÁCIo Marcondes Homem de Melo. Paulista, de Pindamonhangaba. Bacharel de múltiplos talentos. Professor, político, Deputado, Diretor do Banco do Brasil, Presidente de quatro Províncias (São Paulo, Ceará, Rio Grande do Sul e Bahia), homem de letras, historiador, geógrafo, "globe-trotter"... o título de Barão foi-lhe atribuído em 1877.

1855-1858 - 2. ${ }^{\circ}$ BARÃO DE LEOPOLDINA - JOSÉ DE REZENDE MONTEIRo. Era mineiro, bisneto do Inconfidente Capitão José de Rezende Costa. Realizou em São Paulo parte do seu curso jurídico. Bacharelou-se em 1859 pela Faculdade de Direito do Recife. Fazendeiro em Minas Gerais. Deputado Geral. Senador. Barão por decreto de 1879.

1858 - Barão de Ataliba Nogueira - João Ataliba NogueIRA. Campineiro, da terra de Carlos Gomes, de quem foi amigo e admirador até o fim da vida. Fazendeiro, capitalista, figura influente na política monarquista de São Paulo. Barão em 1888.

1858 - VISCONDE DE SÃo VENÂNCIO - VEnÂNCIO JoSÉ DE Oliveira LisboA. Advogado no foro do Rio de Janeiro. Presidente das Províncias da Paraíba e da Bahia. O título foi-lhe concedido pelo Governo de Portugal.

1859 - Barão de Almeida Ramos - JoAquim DE ALMEIDA RAMos. Fluminense. Advogado e Comissário de café na Corte. Barão em 1882.

1859 - Barão? .. Não! - José VIEIRA Couto DE MAGAlHÃes. Este mineiro, de Diamantina, recusou o título de Barão de Corumbá, com que o Governo Imperial queria homenageá-lo pelos "serviços militares prestados na Província de Mato Grosso contra as hordas paraguaias." Na mesma ocasião, preferiu aceitar os galões de General do Exército Brasileiro. (Conforme EugÊNIo EgAS, Galeria dos Presidentes de São Paulo, v. I, p. 756).

1856-1859 - VISCONDE DE SÃo LAURINDo - LAURINDo JosÉ DE Almeida. Paulista, de Bananal. Estudou quatro anos na Academia de São Paulo. Formou-se em Direito na Universidade de Iena, Alemanha. Vereador, Deputado, figura in- 
fluente do Partido Conservador. Agraciado em 1884, pelo Rei D. Luís I, de Portugal, com o título de Visconde.

1860 - Barão de ItAóca - João José Pereira Bastos JúNIor. Fluminense, de Campos, onde foi fazendeiro e chefe político. Barão em 1875.

$1860-20^{\circ}$ Barão de Muritiba - Manoel Vieira Tosta Filho. Baiano, filho do Marquês de Muritiba. Magistrado. Viador da Casa Imperial. Casado com uma filha dos Viscondes de Ubá, a qual foi Dama da Imperatriz e da Condessa D’Eu. Com a República, seguiu para a Europa, acompanhando lealmente a Família Imperial brasileira no desterro. Barão com grandeza em 1888.

1861 - Barão de Itaipe - Carlos Batista de Castro. Mineiro. Magistrado e abolicionista em Minas Gerais. Era sogro do Conde de Afonso Celso. Faleceu octogenário no Rio de Janeiro. Barão em 1889.

1861 - BarÃo dE SANTA EULÁlia - ANTÔNio RodRIgUes DE Azevedo Ferreira. Paulista, de Lorena. Advogado, deputado provincial, fazendeiro. Casado com uma filha da Viscondessa de Castro Lima. Barão em 1888.

1862 - Barão de Barcelos - Domingos Alves BarceLOS CoRDEIro. Fluminense. Fazendeiro. Levantou em suas terras a importante Usina Barcelos, inaugurada com a presença do Imperador e da Imperatriz. Escreveu trabalho sobre A Crise do Açúcar. Barão em 1879.

1862 - Visconde DE Assis Martins - IgnÁcio AnTôNio De Assis Martins. Mineiro. Magistrado, Deputado e Senador. Visconde com grandeza em 1889.

1862 - Barão de Melo e Oliveira - Luís José de Melo E Oliveira. Paulista, de Campinas. Filho daquele que veio a ser o Visconde do RIo Claro. Fazendeiro de café no Município de Rio Claro. Barão em 1885.

1862 - BARÃo DE SÃo MARCELINO - MARCELINO DE Assis Tostes. Magistrado. Presidente da Província do Espírito Santo. Barão em 1889.

1863 - VisCONDE DE TORRES - CÂNDIDO JOSÉ RODRIGUES TORRES JÚNIoR. Fluminense. Filho do Barão de Itambi. Deputado. Viveu depois na Europa, como Ministro do Brasil em Haia. O título foi-lhe concedido pelo Governo português.

1863 - BARÃo de REZENDE - ESTEvão RIBEIRo DE SoUSA REzENDE. Nasceu na Corte. Filho do Marquês de Valença. 
Teve como padrinhos de batismo o jovem Imperador D. Pedro II e a irmã deste, a Princesa Dona Francisca (pouco depois, pelo casamento, Princesa de Joinville). Vereador, Deputado, Senador. Fazendeiro de café e industrial em Piracicaba. Casado com a primogênita dos Barões de Serra Negra. Barão em 1887.

1863 - Barão dE Monte CEDRo - JoÃo José CARnEIRo DA Silva. Fluminense, de Macaé. Filho do Visconde de Araruama. Fazendeiro e estudioso de assuntos agronômicos. Fundou o Engenho Central de Quissaman. Publicista, com algumas obras editadas. Barão em 1881.

1863 - Barão D'AlÉm Paraíba - JoAQUim Barbosa DE CASTRo JÚnior. Mineiro, de Mar de Espanha. Barão em 1888.

1863 - BARÃo DE WERNECK - JOSÉ QUIRINO DA ROCHA WERNECK. Fluminense. Fazendeiro e capitalista. Barão em 1882.

1864 - Barão de Guamá - Francisco Acácio Correia. Natural de Belém do Pará. Barão em 1883.

1865 - $20^{\circ}$ Barão DE JAVARI - JoRge JoÃo DoDSWorth. Era fluminense. Barão em 1889.

1862-1865 - BARÃo do RIO BRANCO - JosÉ MARIA DA Silva Paranhos Júnior. Nasceu na Corte. Filho dos Viscondes do Rio Branco. Estudou quatro anos em São Paulo, onde deixou tradições na vida acadêmica, rememoradas pelo fiel cronista dr. Almeida Nogueira. Formou-se em 1866 na Faculdade de Direito do Recife. Barão por decreto de 30 de maio de 1888.

1867 - Barão do Santo Sepulcro - Diogo Luís de Almeida Pereira dE VAsConcelos. Nasceu em Mariana, Minas Gerais. Católico e monarquista. Na vida pública, salientou-se como político e historiador. Segundo BAsílio DE MAGALHÃes. (Introdução à História Antiga das Minas Gerais, de VASCONCELOS), a distinção foi-lhe conferida pela Santa Sé.

1870 - Barão de Monteiro de Barros - Luís DE Sousa Monteiro DE Barros. Fluminense. Fazendeiro em Minas Gerais. Comerciante de café na praça do Rio de Janeiro. Barão em 1883.

1870 - 2. ${ }^{\circ}$ BARÃo DE SÃo LUIZ - LEOPOLDO ANTUNES MAciel. Gaúcho, de Pelotas. Vice-presidente do Rio Grande do Sul. Presidente da Câmara Municipal de Pelotas. Barão em 1884 . 
1871 - Barão DE CACEQUi - Francisco ANTUnes MaCIEL. Gaúcho, de Pelotas. Cursou de 1867 a 1871 a Academia de Direito paulistana. Aluno distinto, participou no $5 .^{\circ}$ ano de uma rebelião acadêmica, não tendo colado grau em São Paulo. Político influente. Deputado, Ministro do Império, Conselheiro. Irmão do 2. ${ }^{\circ}$ Barão de São Luís. Barão por decreto de 1883.

1871 - Visconde de TeIXeIRA de CaRVAlHo - Joaquim José Teixeira DE CARvalho Júnior. Nasceu na Corte. Advogado. Lente na Faculdade de Direito do Rio de Janeiro. O título proveio do Governo de Portugal.

1872 - BARÃo DE BRASílio MACHADO - BRASÍlIo AUgUsto Machado De Oliveira. Paulista, da Capital. Professor da Faculdade de Direito do Largo de São Francisco. Fundador e primeiro Presidente da Academia Paulista de Letras. Notável advogado e orador. Também jornalista e escritor distinto. Barão por mercê do Papa Pio X.

1877 - CONDE dE Paranaguá - José Lustosa DA Cunha Paranaguá. Era da Corte, filho do $2 .^{\circ}$ Marquês de Paranaguá. Deputado. Presidente das Províncias do Amazonas e de Santa Catarina. O título foi-lhe concedido pela Santa Sé.

1880 - Conde de Afonso Celso - Afonso Celso de Assis FigueIREdo JúnIor. Nasceu em Ouro Preto, Minas Gerais. Filho do Visconde de Ouro Preto. Foi abolicionista e republicano. Deputado, jornalista, lente da Faculdade de Direito do Rio de Janeiro, escritor, um dos fundadores da Academia Brasileira de Letras. Em 1905, mereceu do Papa Pio X a honra de ser Conde Romano, título que em 1911 outro Papa, Bento XV, tornou hereditário.

1882 - Conde José ViCente de Azevedo - José ViCenTE DE AzEvEDo. Paulista, de Lorena. Irmão mais moço do Barão da Bocaina. Deputado provincial e estadual. Lente do Curso Anexo à Faculdade de Direito e do Ginásio do Estado. Sócio fundador do Instituto Histórico e Geográfico de São Paulo. Contribuiu para a criação do Bispado de Lorena. Benemérito, exerceu fecunda atividade católica em prol dos semelhantes. Em 1935, por um Breve Apostólico, recebeu da Santa Sé o título de Conde Romano. 